\title{
THE USE OF SOCIAL MEDIA IN THE COMMUNICATION POLICY OF SMES IN THE COVID-19 CRISIS
}

\author{
Rebecca SPENNER \\ International School of Management, Germany \\ rebecca.spenner@student.ism.de \\ https://orcid.org/0000-0002-6885-3574 \\ Patrick SIEGFRIED \\ International School of Management, Germany \\ patrick.siegfried@ism.de \\ https://orcid.org/0000-0001-6783-4518
}

\begin{abstract}
Atıf Spenner, R. ve Siegfried, P. (2021). The Use of Social Media in the Communication Policy of SME's in the Covid-19 Crisis, Yeni Medya Elektronik Dergisi, 5 (3), 286-313
\end{abstract}

\begin{abstract}
The aim of the study is to find out how SMEs used Social Media during Corona and how customers received it, to determine what should be continued or avoided by SMEs in the future. In this study, an interpretivist approach was adopted through problem-centred interviews with three SMEs. The second part of the study used an objectivist approach, where an online-based survey with a purpose sampling was conducted. The results were evaluated by means of thematic analysis.

The SMEs interviewed considered Social Media essential during Corona. This was due to limited resources and the feeling of being overwhelmed by the situation. For customers a Social Media presence is also considered indispensable, and that the followership is based on the desire for the latest information. However, it also became clear that the survey participants do not believe the information on Social Media and prefer information on the website or at the location itself.
\end{abstract}

No answers could be found about how the experts would answer sans or post Corona. Furthermore, due to anonymisation efforts, it was not possible to clarify the attitude of the survey participants specifically to the individual SMEs.

Keywords: Social Media, SME, SMEs, Covid-19, Pandemic, Communication

\section{COVID-19 KRIZİNDE KOBI'LERIN İLETIŞIM POLITIIKASINDA SOSYAL MEDYA KULLANIMI}

ÖZ

Çalışmanın amacı, KOBİ'lerin Korona sırasında sosyal medyayı nasıl kullandığını ve müşterilerin bunu nasıl aldığını ortaya çıkarmak, gelecekte KOBİ'ler tarafından nelerin sürdürülmesi veya nelerden kaçınılması gerektiğini belirlemektir. Bu çalışmada, üç KOBİ ile problem merkezli görüşmeler yoluyla yorumlayıcı bir yaklaşım benimsenmiştir. Çalışmanın ikinci bölümünde, amaç örneklemesi olan çevrimiçi tabanlı bir anketin yapıldığı nesnelci bir yaklaşım kullanılmıştır. Sonuçlar tematik analiz yoluyla değerlendirilmiştir. 
Görüşülen KOBİler, Korona sırasında sosyal medya kullanımı gerekli görmüştür. $\mathrm{Bu}$, sınırlı kaynaklardan ve durumdan bunalmış olma hissinden kaynaklanmaktadır. Müşteriler için bir sosyal medya varlığı da vazgeçilmez kabul edilmiş ve güncel bilgilere duyulan istek üzerine kurulmuştur. Bununla birlikte, ankete katılanların sosyal medyadaki bilgilere inanmadıkları ve web sitesindeki veya lokasyondaki bilgileri tercih ettikleri de ortaya çıkmıştır.

Uzmanların sans veya post Korona'ya nasıl cevap vereceklerine dair hiçbir cevap bulunamamıştır. Ayrıca, anonimleştirme çabaları nedeniyle, ankete katılanların özellikle bireysel KOBİ'lere yönelik tutumunu netleştirmek mümkün olmamıştır.

Anahtar Kelimeler: Sosyal Medya, Kobi, Kobiler, Covid-19, Pandemi, İletişim

\section{INTRODUCTION}

What started back in 2019 with a mysterious lung-disease in Wuhan, China, and was perceived at the time to be thousands of kilometres away, became the all-dominant topic. Attempts to prevent the spread of Corona led to a radical shut-down of economies. In Germany, the first lockdown started in March 2020, affecting all non-'essential businesses', including many not only the big department stores and brands, but especially small and medium-sized enterprises (SMEs) (Schwartz \& Gerstenberger, 2020; Tagesschau, 2020). Even after the lockdown, in mid-April, circumstances were not yet back to the way they were before the lockdown, but people quickly got used to the 'new normal'. Part of the 'new normal' was also the increased need for information. Special TV-formats reported exclusively on the latest Corona-related developments. However, people did not only look for information in the 'classic media', the thirst for new knowledge about the pandemic also drove them to the internet. This can be seen in a study by AGOF (2020) in the second and third week in March 2020, 58.9 million Germans were online, compared to 59.9 million for the whole of 2019. This means that almost as many people were online in the two weeks as in the whole of last year 2019 combined. Paulsen, Nietan, and Klöß (2020) indicated that this use of 'new media' is not exclusively concentrated on the younger generations, which is hardly possible given the huge number of online users, but that the use of the internet is distributed across all age groups.

Businesses, especially SMEs, have limited capacity to reach customers or be available. One way to inform customers, apart from telephone and window notices, is the new media, especially Social Media. This leads to the question of how SMEs have used Social Media in the Corona crisis, when they are already struggling with limited capacities and have to follow the ever-changing information from the governments, leaving rather little time for something that many companies still see as not necessary for their own business.

In this study, an interpretivist approach was adopted through problem-centered interviews with three SMEs. The second part of the study used an objectivist approach, where an online-based survey with a purpose sampling was conducted. The results were evaluated by means of thematic analysis.

\section{LITERATURE REVIEW AND HYPOTHESIS DEVELOPMENT}

\section{SMEs}

Small and medium-sized enterprises (SMEs) are particularly affected by the Corona crisis (cf. Schumacher 2020). According to a representative survey by the KfW, in 2020, 61\% of SMEs recorded a drop in turnover due to Corona. These companies lost an average of $46 \%$ of their turnover, which means that each affected company must cope with the loss of approximately $€ 46,000$. At the time of the survey (May 2020), German SMEs experienced a total annual turnover of approximately $€ 88$ billion. Many of the respondents also assumed that the consequences of the Corona crisis and the whole string of problems that will follow, will continue to affect them for a long time (cf. Schwartz/Gerstenberger 2020). This means that Germany will continue to be marked by the pandemic for a long time, as the majority of companies in Germany consist of SMEs (cf. IfM Bonn 2019). 
SMEs are present in nearly every sector, and the approaches to defining SMEs are as varied as the fields in which these companies operate. In particular, the distinction between SMEs and family businesses is sometimes unclear, and in Germany at least, a distinction is still made between SMEs and 'Mittelstand'. In this context, the term SME is used precisely when it is a question of quantitative differentiation from large enterprises. The term 'Mittelstand', on the other hand, is often used when it comes to the qualitative differentiation from large companies. (cf. Ulrich 2011: 19 ff.). Nevertheless, the terms SME, medium-sized business, family business, owner-operated business, and family-run business can be considered synonyms, not only because of the ambiguities of differentiation, but also because of the high average number of different types of businesses (cf. IfM Bonn 2020a). However, in order to make a general distinction, especially regarding the question of when a company is considered 'large', the company's size is typically used as a basis. Qualitative criteria are then utilised to define a family business, which can also be a large company (cf. Krämer 2014: 24; Reinemann 2011: 7).

Further definitions are provided by the European Commission, which is also the basis for the German Commercial Code (European Commission, 2003; Fleischer, 2018; Reinemann, 2011). These two definitions expand the quantitative categories by 'balance sheet total'. The definition from the European Commission (EC), which includes the 'balance sheet total' in addition to the previously used quantitative characteristics 'employees' and 'annual turnover'. Furthermore, the subdivision is made differently:

Table 1: SME definition European Commission

\begin{tabular}{|l|l|l|l|}
\hline Company size & $\begin{array}{l}\text { Number of persons } \\
\text { employed }\end{array}$ & Annual turnover & Balance sheet total \\
\hline Micro enterprises & Up to 9 & Up to $€ 2$ million & Up to $€ 2$ million \\
\hline Small enterprises & Up to 49 & Up to $€ 10$ million & Up to $€ 10$ million \\
\hline Medium-sized companies & Up to 249 & Up to $€ 50$ million & Up to $€ 43$ million \\
\hline
\end{tabular}

Source: Own presentation based on European Commission, 2003

\section{German Commercial Code (HGB)}

The definition from the German Commercial Code (HGB; §267) is then derived from this official definition by the EC (Fleischer, 2018).

Table 2: SME definition German Commercial Code (HGB)

\begin{tabular}{l|l|l|l|}
\hline Company size & $\begin{array}{l}\text { Number of persons } \\
\text { employed }\end{array}$ & Annual turnover & Balance sheet total \\
\hline Micro enterprises & Up to 10 & Up to $€ 700,000$ & Up to $€ 350,000$ \\
\hline Small enterprises & Up to 50 & Up to $€ 12$ million & Up to $€ 6$ million \\
\hline Medium-sized companies & Up to 250 & Up to $€ 40$ million & Up to $€ 20$ million \\
\hline Lage companies & More than 250 & More than $€ 40$ million & More than $€ 20$ million
\end{tabular}

Source:Own presentation based on Fleischer, 2018

\section{Deloitte Mittelstandsinstitut}

In the previous three definitions, only quantitative criteria were used for evaluation. Since these definitions are drifting apart, especially concerning the 'annual turnover' and the 'balance sheet total', which makes it difficult to classify a company for example in the event that it comes to legal affairs such as quarrels or the possibility of receiving government support specifically for SMEs, a definition was developed by the University of Bamberg at the Deloitte Mittelstandsinstitut. This definition now considers quantitative as well as qualitative characteristics. To still be considered a medium-sized company according to this definition, the company must possess a 'medium-sized character', meaning 
it is economically and legally independent. In addition, the ownership, control, and management of the company is personal - in other words, these companies are owner-managed or managed by a family (Ulrich, 2011).

Table 3: SME definition Deloitte Mittelstandsinstitut

\begin{tabular}{l|l|l|}
\hline Company size & $\begin{array}{l}\text { Number of persons } \\
\text { employed }\end{array}$ & Annual turnover \\
\hline Micro enterprises & Up to 30 & Up to $€ 6$ million \\
\hline Small enterprises & Up to 300 & Up to $€ 60$ million \\
\hline Medium-sized companies & Up to 3,000 & Up to $€ 600$ million \\
\hline Lage Companies & More than 3,000 & More than $€ 600$ million
\end{tabular}

Source: Own presentation based on Ulrich, 2011

This study utilises the IfM definition, especially regarding the selection of companies for the empirical portion of this study. This is due to the fact that the IfM has adapted its definition to that of the EC and is thus similar in terms of both the number of employees and the annual turnover, especially in the case of micro and small enterprises (IfM Bonn, 2020b; Krämer, 2014).

\section{Types}

According to Krämer (2014), four archetypes of SMEs can be identified. In these four archetypes, six main characteristics are represented with their peculiarities to varying degrees (weak-medium-strong). These types of companies are briefly described below:

\section{Type 1}

The first type comprises a mostly owner-managed company with a simple organisational structure and operating in a niche market. The management behaviour can be described as intuitive, and reactions are less planned and more improvised. Nevertheless, the management style can be classified as authoritarian despite rather flat hierarchies. This type features a close relationship with customers and suppliers, also due to its regional focus. With this focus, this type of company exhibits a high degree of social responsibility. These companies rarely possess a sophisticated controlling or incentive system for the various stake-holders (e.g. employees), and the lack of such a system results in a lack of transparency.

\section{Type 2}

The second type features a high degree of formalisation and, unlike type one, has implemented several systems. This type offers standardised, less innovative mass products for an international market. Due to the large number of systems (planning \& control, control \& incentive), processes in these rather hierarchical companies are kept lean. Due to these hierarchies and centralised decision making, these companies are inflexible. These highly bureaucratically arrested companies feel neither high social responsibility nor a strong relationship with the stakeholders. In the second type, the company objectives are of a monetary nature; the aim is to reduce costs and maximise profits, which is also reflected in a mediocre level of resources.

\section{Type 3}

The third type is distinguished from the first two by its high level of innovation. These companies offer products or services of high quality and novelty, making them performance leaders. Companies of the third type feature a strong financial and human resources base, but only a limited programme, which can be adapted to the customer's needs. Strategic planning is important in these companies, but it is not the focus of attention. The decisions are made together with the employees, so there are few hierarchies and a high level of transparency regarding the employees. This cooperation and involvement of the employees serves these companies as an incentive system in addition to helping them avoid institutional 
controlling. Although these type-three companies possess a strong relationship with internal and external stakeholders, they feature only medium to low social responsibility.

\section{Type 4}

The fourth and final type exceeds the other three types mostly due to its activities on numerous international markets and its higher number of locations. This distribution of locations provides these companies with a high degree of formalisation and pronounced hierarchies. Decision making is usually conducted in the individual divisions, and thus is decentralised, sometimes involving the employees. Despite the companies' size, they can react comparatively flexibly, which can also be attributed to the strong resources available. The variety of products and the high level of resources allow these companies to act as performance rather than cost leaders. To achieve the purely monetary goals and to coordinate all divisions, type-four companies feature a determined corporate planning, which is monitored with a strong controlling and incentive system. As with type two, social responsibility and relationships with the various stakeholders are not particularly pronounced (Krämer, 2014).

\section{Specialties of SMEs}

There are approximately 3.5 million SMEs in Germany, differ from large companies not only in size, but also in special characteristics (IfM Bonn, 2019). One of these specialities includes the dominance of the human factor. This is reflected, on the one hand, in the personal leadership, which contrasts with the management leadership in large companies, and on the other hand, in the personal relationships with the various stakeholders (Immerschitt \& Stumpf, 2019; Krämer, 2014).

In SMEs, the company's economic success is often linked to the economic existence of whole families (Krämer, 2014; Meyer, 2000). In contrast to companies managed by external managers, there is a highly personal motivation to lead the company to economic success (Immerschitt \& Stumpf, 2019; Ulrich, 2011). Furthermore, SMEs often feature strong identification with the employees and a close community with the entire company. Hierarchies are often rather flat, and unlike large companies, there is a wide range of functions (Schulz \& Leder, 2013; Ulrich, 2011). These institutional characteristics are also reflected in the companies' management, which consists of people who lead intuitively and are described as generalists who improvise rather than acting systematically and in a coordinated manner (Immerschitt \& Stumpf, 2019; Krämer, 2014; Ulrich, 2011).

Due to the fact that many SMEs are affiliated with their region, they experience a social responsibility towards this region and its people (Immerschitt \& Stumpf, 2019). Both the customers and the suppliers will have been in contact with such companies for many years. Due to this long-lasting relationship, it is a peculiarity of SMEs that they have to consider the different interests of external and internal stakeholders in their decisions in order to be and remain successful (Krämer, 2014). However, these decisions are made by the management even if they are not of economic importance and could possibly be made by the employees themselves (Ulrich, 2011). On the one hand, this is due to the connection between the company and the entrepreneurs' personal economic existence. On the other hand, it is also due to the fact that entrepreneurs manage intuitively and rarely in a delegative fashion (Ulrich, 2011). As a result, many of the decisions are of an operational nature, and less attention is paid to strategic planning, which is rarely recorded in writing and even less frequently reviewed for achievement (Krämer, 2014; Ulrich, 2011).

Despite the high level of customer proximity and the often high quality of service, SMEs are considered to possess a limited capacity for innovation, partly due to limited resources, both human and financial. Furthermore, SMEs usually possess little equity, and therefore must resort to loans, but since SMEs usually also possess a rather weak market position, obtaining capital is typically associated with high costs. Additionally, SMEs tend to employ fewer academics and more skilled workers, but these have an extremely high level of qualification. This imbalance is due to the fact that SMEs are considered by many to be unattractive. Specialists and managers prefer large companies due to better career opportunities and higher salaries (Hakansson \& Klandt, 2000; Krämer, 2014).

As far as the use of information and communication technology is concerned, SMEs only indicate that the larger a company is, the more complex the systems are, and the more likely it is that the company will possess its own IT department, no matter how large it ultimately is. However, what can be seen as 
specific to SMEs is that, when technology of this kind is available, it tends to be less adaptable and is designed and purchased for 'the moment'. However, this speciality can be explained by the low strategic orientation of many SMEs (IfM Bonn, 2020a; Krämer, 2014).

In summary, although these specialities distinguish SMEs from large companies, they are not present in all SMEs to the same extent. Furthermore, the limited financial and human resources in SMEs mean that many tasks also have to be performed by management, which in this case is less able to plan strategically, which subsequently limits the scope for taking steps for the future, such as technologically or in terms of internationalisation.

\section{Social Media}

As the Internet developed, social networks evolved. The first websites where users could get in touch with each other consisted of discussion forums. Today's social networks still retain this factor of users getting in touch with others, no matter whether they are private individuals, business partners, or entire companies and brands (Kreutzer, 2018). These social networks work through social software, though just as with Web 2.0, there remains no generally accepted definition for this term. Often, social software is summarised with software systems in general and understood as programs that support communication, interaction, and collaboration between people (Hinterholzer \& Jooss, 2013). In his consideration of social software, Krämer (2014) added the definition of Cook and enriched it with the definition provided by Schmidt. Cook states that social software possesses the functions of network building, collaboration, and communication (Cook, 2008). Schmidt leaves out the collaboration factor and views the functions as relating more to the management of relationships, information, and identities (J. Schmidt, 2006). Apart from the cooperation factor, the following list of factors common to all social networks confirms these definitions.

All social networks possess the same four basic functions: First, users create a profile intended to tell other users who the person is, what they are interested in, and so on. Second, beyond the basic information a profile offers, users can also add further elements to this. These elements include, for example, posts in the form of photos, videos, texts, and external links. The next function concerns the display of contacts, revealing who the user has 'connected' to in this network. The fourth and final function is the most original - namely, communicating with other users in this one network. This can occur one-to-one between two users privately or in private or public groups with several people. Some networks have created a communication service for this purpose or are based solely on this factor, such as WhatsApp (Kreutzer, 2018).

In this study, the definition of social networks is based on the definition of social software, as these definitions correspond to the applications of Social Media, and experts understand the term 'social software' only as the technical consideration of the topic. As such, social networks describe platforms on which people network, communicate, and collaborate on the Internet using images, sounds, and text (Bendel, 2020). Over the course of time, several Social Media platforms have appeared and disappeared (Cleffmann, Feuerabend, Kollmann, \& Zoebeli, 2013; Fischer, 2019). Those that remain active and market-determining today have continued to develop. Therefore, making a clear distinction between social networks, messenger services, and media-sharing platforms has become increasingly complicated (Kreutzer, 2018). As previously mentioned, there is a rise and fall to Social Media. Sites such as Myspace, ICQ, and MSN used to be essential for users for a while, but then eventually died out.

\section{Social Media and SMEs}

Social Media has become an integral part of the everyday life of many consumers, which is why more and more SMEs have established a presence in such networks since at least 2013. Many of these companies are aware of the diversity of Social Media, and indeed, the platforms offer considerable potential, such as establishing close customer contact and becoming 'good friends' (A. Schmidt \& Hoyer, 2012). However, in 2013, Social Media was not seen as a success factor for SMEs; rather, many SMEs were simply overwhelmed by these diverse possibilities (Creditreform, 2012). In a study published in 2013 with 400 participants, the Vienna University of Economics and Business 
Administration and the University of Liechtenstein stated that Social Media is not a success factor for SMEs and that such overstretch largely occurs due to a lack of resources. The basic requirements, such as human resources with the proper know-how, must be created first. At the same time, the goals sought by many SMEs via Social Media, such as increasing awareness, customer acquisition, and improving customer relations (it\&t, 2014; Wintermann, Baethge, \& Boberach, 2018), can only be achieved if the Social Media follows an entrepreneurial approach, takes risks, and demonstrates a proactive and innovative attitude (Industrieanzeiger). However, in the 2013 study, those responsible within the SMEs seem to be afraid of possible damage to their image. This fear is also reflected in the fact that almost $20 \%$ reported being unsure whether and to what extent Social Media can benefit their own company, and $16.2 \%$ of the decision-makers expressed the opinion that Social Media is simply not important in the respective industry. However, this last statement contradicts the claim made by almost $7 \%$ of the respondents that competitors do not use social networks. Conversely, this means that approximately $93 \%$ of the competitors use social networks, illustrating some inconsistency in this respect. The study also found that SMEs consider Social Media to be inexpensive and less time-consuming. This consideration of Social Media as less complex is also indicated by the fact that controlling takes place only to a rather small extent and almost exclusively of a quantitative nature (A3Marketing, 2013).

Three years later, a new study, 'Mittelstandskommunikation 2016', was conducted as a cooperation between the University of Leipzig, Fink \& Fuchs AG, and the magazine Presseprecher (Fink, 2016b). Among the 561 companies surveyed, 270 decision-makers from SMEs also expressed their opinions. In 2016, the goals were also clearly focussed on increasing awareness (90.4\%) and building or strengthening their own brand (85.2\%). The companies further identified establishing and maintaining a customer relationship as communication goals. Not much had changed in the past three years, and goals such as employee motivation or crisis management were relegated to the bottom of the list (cf. (Zerfaß, Fink, \& Winkler, 2016). The problems had not changed much either, with the lack of resources, largely financial, remaining the biggest (Fink, 2016a). However, this time, the respondents also identified the lack of a communication strategy as an obstacle. The sense of digital business communication was also still questioned, with $9.3 \%$ claiming that the fear of negative reactions is always present, and clear responsibilities are also often lacking. However, these obstacles are not reflected in the reluctance to use social networks, as $84.1 \%$ of the respondents claimed they use social networks in their communications, and only $74 \%$ stated that these networks are important. Regardless, the percentage of companies that carry out controlling has also risen significantly. More than $60 \%$ of respondents stated that they measure their success. Furthermore, many of the surveyed companies focussed more on sales, demonstrated by the fact that only $33.7 \%$ conduct an active dialogue on the Internet, though the respondents admitted that active dialogue is important (55.3\%) (Fink, 2016b). What is also apparent here, however, is that the management in SMEs is of considerable importance, due to the fact that if the management supports communication measures, it will also adapt to the change (Fink, 2016a). This strong influence of the management could already be seen in the previous sections, which clarifies the possibility of typification of SMEs. Other smaller surveys in 2018 and 2020 revealed that SMEs still do not have Social Media well under control. Under the direction of Prof. Bettina Fischer PhD., 58 companies were surveyed by the Rhine-Main University of Applied Sciences in 2018 for a qualitative review. The companies consider the use of social networks to be quite significant, but they still do not exhibit any strategic orientation in their Social Media efforts. This lack of strategy can also be seen in the fact that the respondents cited a lack of time as an obstacle, and thus only conduct limited controlling. Companies still lack resources and know how to plan and use Social Media profitably (Munz, 2018). In 2020, the market research institute Civey surveyed 500 SMEs regarding their use of Social Media, also taking into account the Corona crisis. The results revealed that Social Media continues to be used, especially in times of crisis, to achieve the goals of customer acquisition, customer loyalty, and increased awareness through marketing, as already mentioned in 2013. Especially if the SMEs' decision-makers were in the younger semesters, a high level of satisfaction concerning the use of Social Media for customer acquisition and loyalty can be seen. This new research again illustrates that a lack of knowledge regarding the profitable use of Social Media prevents many companies from establishing a Social Media presence in the first place. As a result, $86.5 \%$ of companies without a Social Media presence do not plan to establish one in the future. Approximately only $4 \%$ were affected by the 
Corona crisis and the restrictions and problems associated with this for becoming active in social networks (Hohmann, 2020).

Over the years, it has thus become clear that Social Media and its relevance for business has been well received by SMEs, but it still fails due to the will of the management, lack of strategy, limited resources (human and financial), and a fear of negative feedback. Regardless, the companies' objectives have evolved from the 'original' objectives, such as customer acquisition, relationship management, and awareness raising. It can also be noted that even a major crisis such as Corona seems to change little in the companies' behaviour, at least in terms of communication and Social Media (Fink, 2016b; Hohmann, 2020; Munz, 2018).

\section{Differences between SMEs and large companies in the use of Social Media}

One of the primary reasons for the differing use of Social Media by SMEs and large companies concerns the digitalisation of companies, because only those who know and possess the technical possibilities can use Social Media. There is also a difference within the SMEs, as small companies with a maximum of nine employees exhibit the same high degree of digitalisation as large companies. The middle group of SMEs lacks this degree of digitisation, but this gap is also decreasing (Wintermann et al., 2018).

The general use of Social Media is equally widespread among large companies and SMEs (Ambrosch, 2020), but differences can be seen, above all, in the choice of platforms. On the common platforms such as Facebook, Instagram, and LinkedIn, the types of companies are equally well represented, and even if they possess their own blogs, SMEs and large companies are equally well represented despite the fact that they may be more labour-intensive. Differences also exist on YouTube and Twitter, as SMEs are active less often and large companies are also stronger in the operation of Wikis or online communities, partly due to the resources, but also because of the need to build up knowledge collections such as a Wiki in the first place (Arns, 2012).

As SMEs' goals are focussed on reaching the customer, as stated in previous sections, the next difference concerns the use of Social Media in relation to their own (future) employees. According to one study, $27 \%$ of the large companies use platforms for HR issues compared to only $8 \%$ of SMEs, and more than a third of large companies conduct market research on Social Media, whereas only $17 \%$ of SMEs do so (Arns, 2012). Although both company types share a similarly strong focus on increasing awareness through Social Media, according to Bitcom, the next difference lies in the way this is achieved. Large companies employ Social Media roughly twice as often to build relationships with multipliers as journalists. Overall, the difference between these company sizes is that SMEs plan and implement Social Media in a less targeted and strategic manner (Arns, 2012).

This lack of a strategy is associated with the often limited resources of SMEs. This impact of resources is also demonstrated by the fact that only $10 \%$ of SMEs can afford to engage an external service provider for Social Media, which could make up for any lack of human resources and know-how. Large companies, by contrast, employ such external services three times as often, and the 'fear of using Social Media in SMEs' again reveals the dependence on resources. Specifically, SMEs are less likely to have a legal department to deal with potential pitfalls (Arns, 2012).

Even if there are more detailed differences between SMEs and large companies regarding their use of Social Media, it should be noted here that, in addition to the difference factor 'resources', the factor 'professionalisation' can be seen as a decisive difference. In many SMEs, Social Media is conducted on the side or by a few responsible persons, whereas in large companies, this is dealt with by entire departments in cooperation with external service providers. Even if this can be attributed to resources, the lack of guidelines and training in particular reveals that Social Media is conducted less professionally by SMEs, as whether or not a company handles something professionally depends on the company's size, because otherwise, according to this theory, every small company would work unprofessionally and only large companies would work professionally (Knickmeier, Esslinger, \& Schwering, 2013)). 


\section{Success factors of strategic Social Media use in SMEs}

Even though, in 2013, Social Media was not considered a success factor for SMEs, and many companies exhibited signs of being overburdened in later years, Social Media continues to be used by many SMEs and, with the proper strategies and resources, they are seen as offering potential for the future. Due to the diverse design possibilities involved, Social Media offers a wide range of potential benefits, and thus high compatibility for SMEs (Krämer, 2014; A. Schmidt \& Hoyer, 2012). However, like so many others, this success is also subject to conditions. As stated in the previous sections, the attitude of the managing director is essential for Social Media success, so a condition for success is that the company offers not only a supportive positive environment, but also an open corporate culture, which should begin with the managing director (Weis, Hofer-Fischer, \& Kremmel, 2013; Winkler, 2020). At this organisational level, it is also important that both the entire company is behind Social Media from the very top and that the corporate culture matches (Weis et al., 2013). Factors such as the age of the workforce play a role here, as it is not necessary for 'digital natives' to grow used to Social Media, since they take it for granted. Accordingly, employees who must grow used to this should be offered opportunities to acquire this specific knowledge, such as through training (Caprano \& Ergenzinger, 2013). Like the social web, the corporate culture must also be open, participative, and convey authenticity so that it becomes part of everyday life in the company itself, allowing it to act dynamically and cooperatively in dialogue (Meyer, 2013). To this end, management must provide rules, such as Social Media guidelines (Creditreform, 2012). Within these limits, however, employees must be allowed to move freely, and thus provide a scope for creativity. These regulatory factors can be seen as part of the structural level of success factors. However, this level also includes the provision of a separate budget for Social Media and the consistent integration of support along the entire value chain (Caprano \& Ergenzinger, 2013).

A fundamental success factor concerns the strategic level. The frequent lack of a clearly formulated strategy covering the entire company has already been highlighted in previous sections as one of the reasons for failure. Therefore, it is essential to formulate this strategy in line with the customer's specific communication needs and the company's own capabilities (Meyer, 2013).

A further success factor derives from the customer perspective, such as integrating and listening to the customers. Therefore, SMEs must also interact with customers on their platforms not only to build customer loyalty, but also to determine what content appeals to the customer, due to the fact that creating interesting content represents one of the greatest challenges. However, this challenge must be met, because users will take away the 'like' and 'follow' of Social Media sites if the content does not add value, and only the user himself can tell what this value is (Caprano \& Ergenzinger, 2013; Cleffmann et al., 2013). Social Media means communicating with customers and not simply using information to persuade them to buy. The dialogue must take place at 'eye level', which is why SMEs must also exhibit openness, closeness, and empathy online, as well as accept and use criticism profitably (Caprano \& Ergenzinger, 2013). This dialogue can be strategically limited to a few topics and platforms, which takes account of the excessive demands and limited resources (Winkler, 2020). Furthermore, SMEs must be courageous and try things out. Beyond this, they must also act entrepreneurially online in order to identify forward-looking target groups, as the authors of the first study pointed out in 2013 (Industrieanzeiger). 
Table 4: Working hypothesis

\begin{tabular}{|l|l|}
\hline$\#$ & Working hypothesis \\
\hline WH1 & The majority of companies have a Social Media strategy \\
\hline WH2 & $\begin{array}{l}\text { The choice of Social Media in particular SN is based on the companies' knowledge of their } \\
\text { customers }\end{array}$ \\
\hline WH3 & $\begin{array}{l}\text { The companies use Social Media to communicate with their customers, therefore only } \\
\text { beneficial messages that are adapted to the channels are played. }\end{array}$ \\
\hline WH4 & $\begin{array}{l}\text { During Corona the focus of Social Media efforts was on maintaining contact with } \\
\text { stakeholders, so that (new) customer acquisition was less focused. }\end{array}$ \\
\hline WH5 & $\begin{array}{l}\text { The existence of a strategy makes SMEs feel secure in relation to Social Media, regardless of } \\
\text { any possible classification, even in times of crisis. }\end{array}$ \\
\hline WH6 & $\begin{array}{l}\text { The companies initially underestimated Corona's economic impact and therefore did not } \\
\text { change their Social Media strategy. }\end{array}$ \\
\hline WH7 & $\begin{array}{l}\text { As a result of Corona, companies have been less willing to take risks with regard to the } \\
\text { content in Social Media presentations. }\end{array}$ \\
\hline WH8 & \begin{tabular}{l} 
It is important for customers to be involved in Social Media by the company. \\
\hline WH8.1
\end{tabular} $\begin{array}{l}\text { Customers use Social Media in relation to companies to obtain detailed and timely } \\
\text { information on current events such as re-openings and current services. }\end{array}$ \\
\hline WH8.2 & $\begin{array}{l}\text { Part of the companies' Social Media strategy is the active involvement of customer feedback. } \\
\text { The increased need for information on Corona is also reflected in the structure of companies' } \\
\text { Social Media content, more than half of the Social Media content has a Corona reference. }\end{array}$ \\
\hline WH9
\end{tabular}

\section{RESEARCH METHODOLOGY}

The research in this study will be based on ontology through an interpretivist approach. It is based on the assumption that individuals experience reality simultaneously but grasp different aspects of it, which in turn is influenced by prior social interaction and culture. Thus, individuals always perceive and interpret reality subjectively and it differs from person to person (Saunders, Lewis, \& Thornhill, 2015). The rationale for choosing this approach is that communication policy partly aims at influencing the individual's perception of the situation (Bruhn, 2014). The interpretivist approach, instead of the positivist approach, is to analyse the individual's perception of the crisis, i.e. how the participants perceived the situation and thus built a reality for themselves (Saunders et al., 2015). In the second part of the field research, however, an objectivist approach is followed due to the quantitative nature of the online survey. Because of the fact that in this work different approaches merge into each other and the research is both qualitative and quantitative in nature, the researcher finds herself in the role of a detective as well as in the position of a scientist (Saunders et al., 2015).

\section{Data Collection}

The collection of data is done through the creation of primary data. For this purpose, qualitative semistructured interviews will be conducted with three. The sampling will follow a purposive sampling approach (Fisher \& Buglear, 2010). The selection of SMEs is subject to the criteria of representing manufacturing industry as well as service providers and retail trade SMEs (Bakery, medical services \& decoration store). The interviewees differ in age, gender and period of business ownership. The interviews are expected to last between 30 minutes and one hour (Saunders et al., 2015). 
Table 5: Company \& interviewees names

\begin{tabular}{|l|l|}
\hline Company sector & Interviewees \\
\hline Bakery & I1 \\
\hline Candles & I2 \\
\hline Physiotherapy & I3 \\
\hline
\end{tabular}

The second part of the primary data collection will take place through an online survey. The sampling approach will be purposive sampling. As the survey is addressed to the customers of the respective SMEs, e.g. by displaying a QR code in the business premises or posting the survey link on the online platforms belonging to the SMEs. This results in a simple random sampling from the totality of the customers with the participants/answers. The targeted interviews have a problem-centred character, they focus exclusively on the topic of the work. Furthermore, the interviews will follow the phases developed by Döring and Bortz (2016). According to this, the interviews start with an explanation phase, in which the interviewer informs about the circumstances of the interview and the topic (Kurz, Stockhammer, Fuchs, \& Meinhard, 2009). In this part, the participant is also assured that the answers will be treated confidentially and anonymity is guaranteed. It is also explained that there will be no evaluation of the answers, so that the participants know that there are neither right nor wrong answers. This is followed by a request for biographical data (Döring \& Bortz, 2016).

The semi-structured interviews require an interview guide. This will contain the most important questions and themes that have emerged from the working hypotheses. These are in turn based on the critical literature review and the previous theoretical discussions. When the interviews are conducted, the actual order of the questions may change, depending on how the interviews proceed (Bogner, Littig, \& Menz, 2014). Furthermore, ad-hoc questions based on the guide can occur if necessary. These serve to clarify or specify explanations given by the interviewee. This increases the quality and counteracts misunderstandings (Kurz et al., 2009). The interview guide serves as an orientation aid and also makes it possible to compare the interviews. A certain level of standardisation is created by the uniform aspects of the guide.

The standardised online survey, requires a fixed sequence of questions. This will include the most important specific questions and themes that have emerged from the working hypotheses. These are based on the critical literature review and the previous theoretical discussions. The sequence is subject to thematic order as well as psychological aspects, such as asking the demographic questions at the end to avoid a break-off at the beginning and to build trust. The answer options will never contain more than seven options so as not to overwhelm the participant. A pre-test is conducted to prevent misunderstandings and comprehension problems (Raab-Steiner \& Benesch, 2012). Ten people will fill in the questionnaire on paper and write down commends.

The interviews are recorded with the permission of the participants and special aspects or anchor points for follow-up questions are noted by hand. Later, the transcription takes place and a copy is sent to the participant. This gives the opportunity to change, add or delete statements (Döring \& Bortz, 2016). Only with the participant's approval does the analysis take place.

\section{Data Analysis}

Due to the subject matter of this study, it is advisable to consult the thematic analysis according to Braun and Clarke (2006) for data analysis. The reason for this is that thematic analysis does not correspond to basic methodological assumptions and is therefore very flexible and adaptable. As a result, it is used in a wide range of disciplines (MAXQDA, 2021). This suits this study as it is intended to provide first tentative steps in researching the impact of Corona on SMEs. The aim is thus not to create a plausible robust theory that can be verified by data. Rather, in correspondence with the thematic analysis of Braun and Clarke, a detailed description of the acquired data is to follow. In keeping with the selected analysis method, the aim is thus to penetrate behind the obvious and superficial content and to decipher a meaning, as well as to make transparent what lies behind it. A further advantage of this analysis method, 
in view of the mixed survey methods and the resulting different data formats, is that this method can be used independently of the survey method and with existing data (Flick, 2017; Stainton Rogers, 2011).

\section{RESULTS}

The evaluation of the quantitative survey was divided into gender and between Social Media users and non-users. A division into age groups was largely omitted in the detailed examination of the outcomes, as the answers of 21-30-year-olds, for example, did not significantly differ from those of 51-60-yearolds, as, for example, both age groups selected here as examples possessed a main interest in following SMEs on Social Media in order to obtain the latest information. Only in the use of the individual Social Media channels did differences arise; among the age groups, TikTok is only present in the younger participants, and Instagram is more significant in the younger age.

\section{WH1 The majority of companies have a Social Media strategy.}

Except for the Bakery, none of the interviewees agreed that they possess a Social Media strategy and proceed according to it. In summary, it can be said about the feedback collection and implementation component that the SMEs accept feedback, but do not implement continuous collection, and this is largely performed in a two-way conversation. The SMEs also unanimously stated that they did not set budgets and that they did not have a staff member who consistently takes care of Social Media. In all three companies, the responsibility for Social Media resided with the management. Furthermore, even if the companies, according to the indicators and their own statements, have not written down a strategy and only use Social Media because it 'belongs', is 'necessary', and is 'popular', all three experts stated that they do control Social Media activities.

For the first working hypothesis, it can thus be stated that only one of the interviewed experts has drawn up a Social Media strategy for his SME. At the same time at least partial components of a strategy are employed in the SMEs and that, despite all three SMEs lacking a written, defined strategy nevertheless, they monitor their Social Media efforts and draw conclusions from them.

\section{WH2 The choice of Social Media (and social networks in particular) is based on the companies' knowledge of their customers.}

The companies unanimously stated that they are active in Social Media because they think they can reach their customers there. However, the choice of platforms is also based on personal experience and use of the platforms. I2 stated that she decided to use Facebook in the beginning due to the fact that she also uses it privately and has seen how others have used it for professional purposes. I1 also stated that he found the handling of the platforms Facebook and Instagram more pleasant than that of Twitter. Furthermore, one would have noticed that the customers, especially the younger ones, are more likely to stay on Instagram and that their own user behaviour has also changed with the growth of the Instagram platform. I1 likewise stated that his young employees and assistants also make him aware of new trends and channels. I3 chose her Social Media channels because she considers them to be the most common (i.e., most popular). The addition of YouTube, however, was based on the fact that she or her employees had expressed the desire to offer the courses online during the lockdown and to integrate them on the website, but this channel was also taken up due to customer requests.

\section{WH3 The companies use Social Media to communicate with their customers; therefore, only beneficial messages that are adapted to the channels are played.}

The majority of the companies utilised Social Media primarily for communication purposes, focussing on the factor of promotional communication due to the nature of SMEs. Both I2 and I1 stated that they want to acquire and communicate with customers through Social Media, such as by inviting interaction in either the form of surveys in stories or by linking the business to the customers' photos. Only I3 stated that she uses Social Media only to be present and inform her customers and is less concerned with communicating and interacting to build a relationship. At Physiotherapy, even if the news is negative, it is published directly without being modified specifically, but I3 attempted to adapt the other news to the channels, such as by using different visual components or wording. At Candles, there has not been any negative news during business hours so far, but generally, the topics are selected 
specifically and then posted on Instagram and directly on Facebook through a software offer from Facebook Inc.. The Bakery also uses the Facebook tool, and thus does not change the message in relation to the channel. Regarding the point of negative news, according to I1 's statement, in the more than 40 years of operation, there has not been any negative news, and if there was, such content would not be posted.

\section{WH4 During Corona, the focus of Social Media efforts was on maintaining contact with stakeholders, so less focus was placed on (new) customer acquisition.}

I3 stated that the goal during Corona was to keep customers up to date with the latest developments. Candles also sought to inform customers about what was happening and the possibility of reopening soon. The Bakery likewise aimed to inform customers that they are not affected by the lockdown and that they can now also buy 'crisis products', such as flour and yeast. Physiotherapy stated that one of their goals was to increase their experience in Social Media and that they were more willing to take risks and try more Social Media postings. I2 further claimed that they tried a new service, consisting of free delivery if the products bought are worth more than $€ 50$ to keep customers, but despite the goal being to keep customers, she also stated that she was rather quiet in Social Media during the Corona period. In all three SMEs, the interviewed experts thus indicated that the main focus was on retaining customers.

\section{WH5 The existence of a strategy makes SMEs feel secure in relation to Social Media, regardless of any possible classification, even in times of crisis.}

Only one company claimed to utilise a strategy, even if it is not set down in writing. Regarding the Bakery, I1 stated that they adhered to the strategy present in his head. As the other SMEs also possess sub-components of a strategy according to the answers to working hypothesis one, they were also asked how far they have naturally continued Social Media during Corona. I2 stated that she had posted less, but at least once a week, and that her rules helped her keep to her daily routine. I3 claimed there were no changes in Social Media during Corona, but as she has no rules, it is not clear if they would have given her more security.

\section{WH6 The companies initially underestimated Corona's economic impact, and therefore did not change their Social Media strategy.}

All three SMEs stated that they had underestimated Corona, including due to the great distance from the virus' country of origin. The companies also have not changed their Social Media practices. All three stated that they were facing considerable losses. However, some specificities can be observed due to the SMEs' different industry affiliations: Physiotherapy was able to flatten the sales collapse as well as decreasing profits by treating patients, especially after the lockdown, but this SME still experienced losses in relation to membership applications for sports courses or the cancellation of such membership especially for example for the training on equipment. Candles stated that the regular customers not only came back after the re-opening, but they even experienced an increase in customers. I1 had to cope with a drop in turn-over of at least $60 \%$ due to missing cake orders and deliveries of rolls and snacks. However, with its well-known 'toilet paper cake' and the sale of flour, yeast, and sourdough, the Bakery was able to get back on its feet and dispense with the registration of short-time work, even hiring additional staff. Despite the fact that the SMEs claimed to have underestimated Corona, corona became relevant for postings on Social Media, even at the beginning of the pandemic.

\section{WH7 As a result of Corona, companies have been less willing to take risks regarding the content in Social Media presentations.}

Two of the three SMEs have tried out new things, at least to some extent, and thus have also taken the risk of failure. The companies have tried out new things on Social Media; for example, I3 opened a YouTube channel for Physiotherapy and uploaded videos of recommended sport exercises there. At the same time, she also stated at the beginning of the interview that she wanted to gain experience in Social Media and was more joyful in trying things out in relation to Social Media. At the Bakery, photos were linked, for example, to reports about the 'toilet paper cake'; according to I1, this had previously been done in the past with celebrity cake orders, such as from BVB players, but more intensively during 
Corona. I1 also stated that he was more concerned about Social Media performances and that he now uses hashtags differently, becoming more creative overall.

Only I2 felt highly overwhelmed by Corona, so she did not become more risk-averse in her Social Media efforts, but instead introduced a new service.

WH8 It is important for customers to be involved in Social Media by the company.

Among the available reasons for following SMEs on Social Media, the respondents chose the answer option 'interaction with the company' as the least common, regardless of gender. Additionally, in the later weighting of the reasons for following Social Media, the 'interaction' option was rated ' $1=$ not important' by almost $40 \%$ of women and almost $35 \%$ of men (see Figure 2 ). However, the survey indicated that the respondents largely follow companies on Social Media because of the possibility to obtain the latest information and be offered interesting content. Furthermore, simple contact by Social Media was listed by respondents as the third most frequent reason, regardless of gender. Among the men interviewed, 'interaction with likeminded people' was also mentioned as an important reason for following Social Media (see Figure 1). Among the women, only 5\% of those interviewed rated this as '5=very important' (see Figure 2).

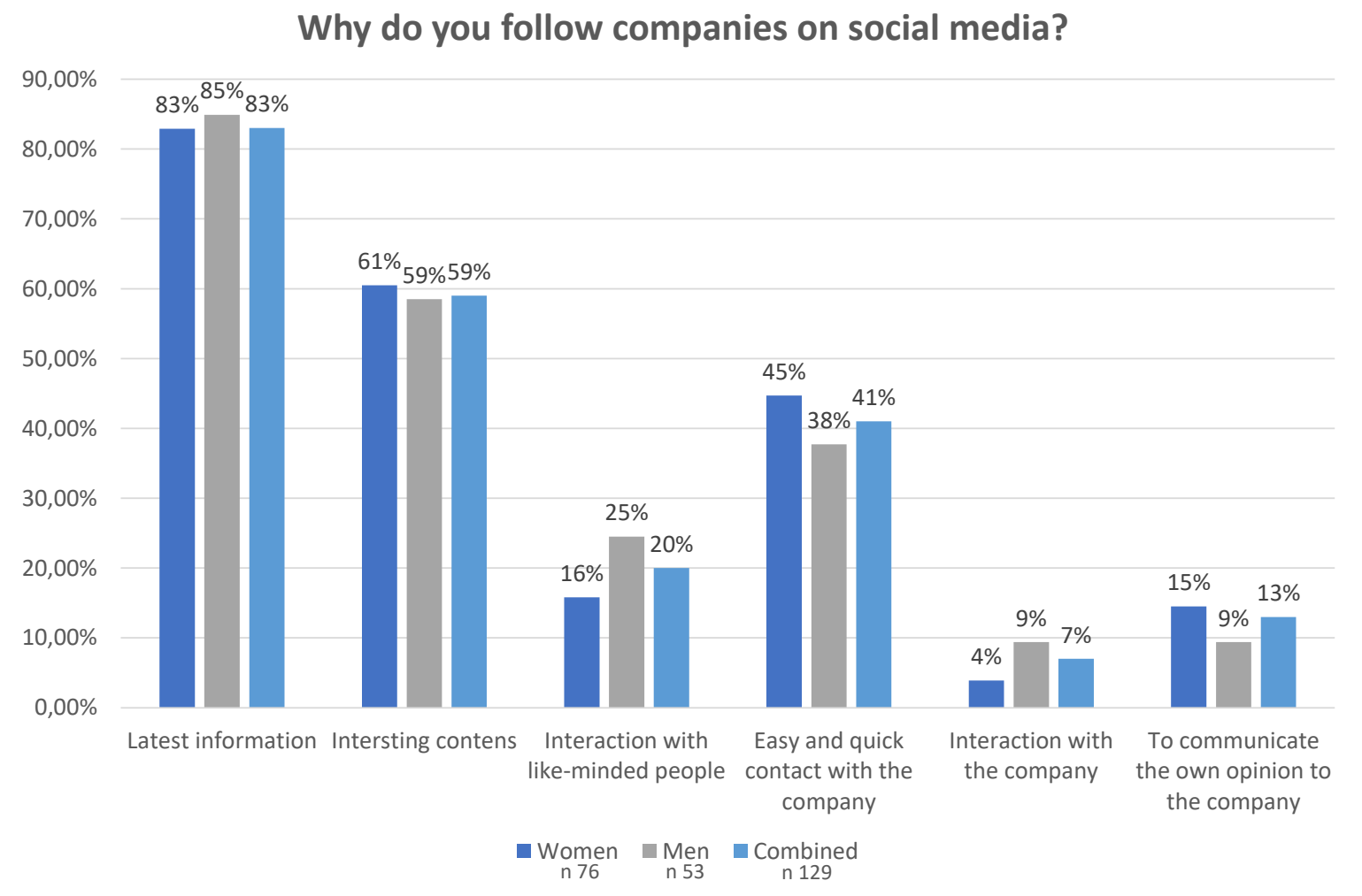

Figure 1: Why do you follow companies on Social Media?

Source: Own survey 

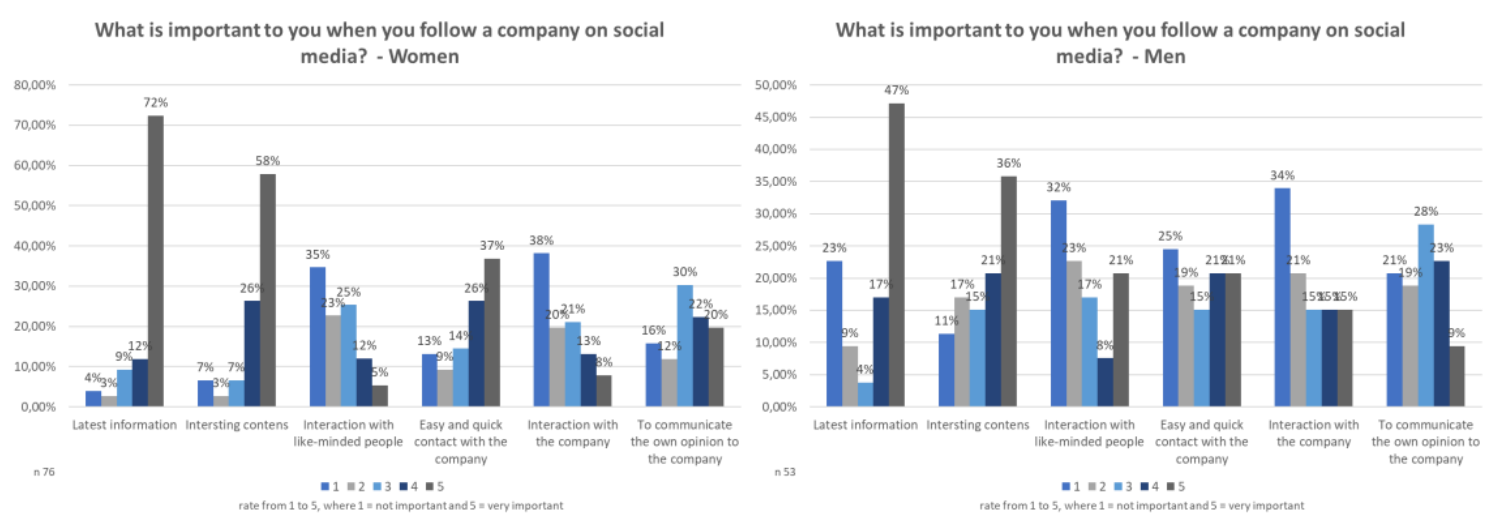

Figure 2: What is important to you when you follow a company on Social Media? (Differentiation between women and men)

Source: Own survey

WH8.1 Customers use Social Media in relation to companies to obtain detailed and timely information on current events, such as re-openings and current services.

As previously mentioned in the evaluation of working hypothesis eight, the respondents, irrespective of gender, stated that the reason for people to subscribe to SME channels on Social Media is, above all, to obtain the 'latest information'. An estimated $82 \%$ of the women and almost $85 \%$ of the men listed this as a reason, followed by 'interesting content' (women $60 \%$, men $58 \%$; see Figure 1). Furthermore, in the subsequent weighting of the importance of the reasons, 'latest information' and 'interesting content' were the most important for both genders (see Figure 2). Participants also agreed that the information on the SME Social Media channels is more up to date, easier to find, and more accessible compared to the website or printed information. Women in particular, at almost $80 \%$, stated that they found it easier to access information via Social Media, while $64 \%$ of men reported likewise (see Figure 3). This focus on information and interesting content, as well as the respondents' opinion that it is easier to find information using Social Media, is also reflected in how people want to be informed. The most common option consisted of 'image/graphics and text', followed by 'image/graphics only' and 'film/video and text', with $34 \%$ of men and $22 \%$ of women indicating that they receive information via film or video (see Figure 4).
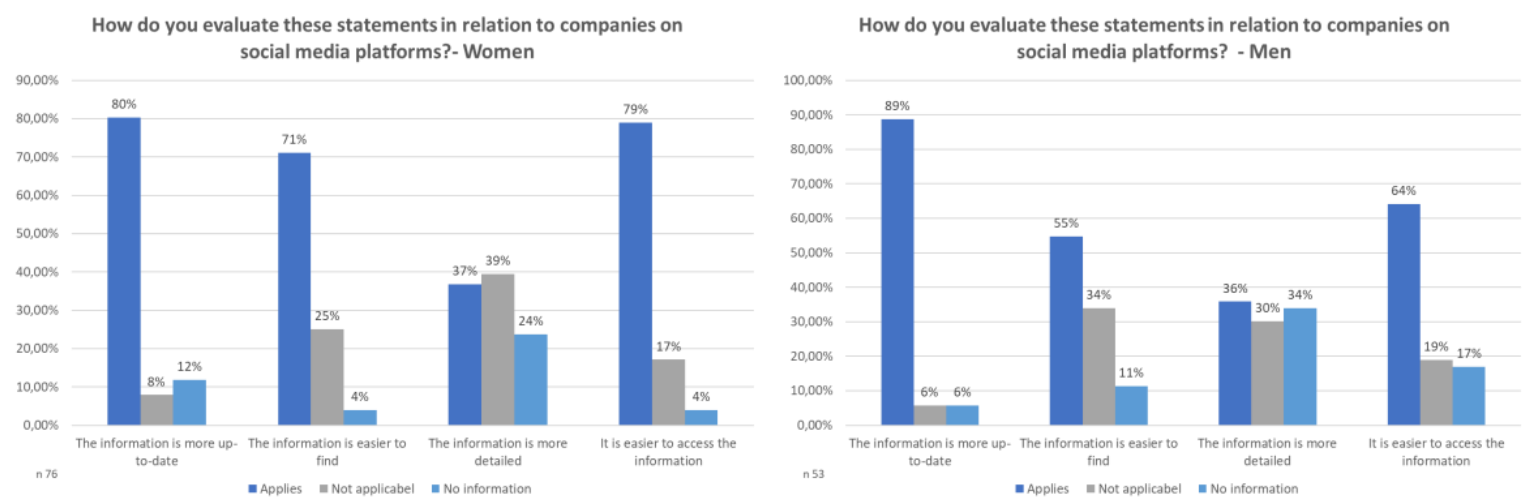

Figure 3: How do you evaluate these statements in relation to companies on Social Media platforms? (Differentiation between women and men)

Source: Own survey 


\section{How would you like to be informed by the companies on social media?}

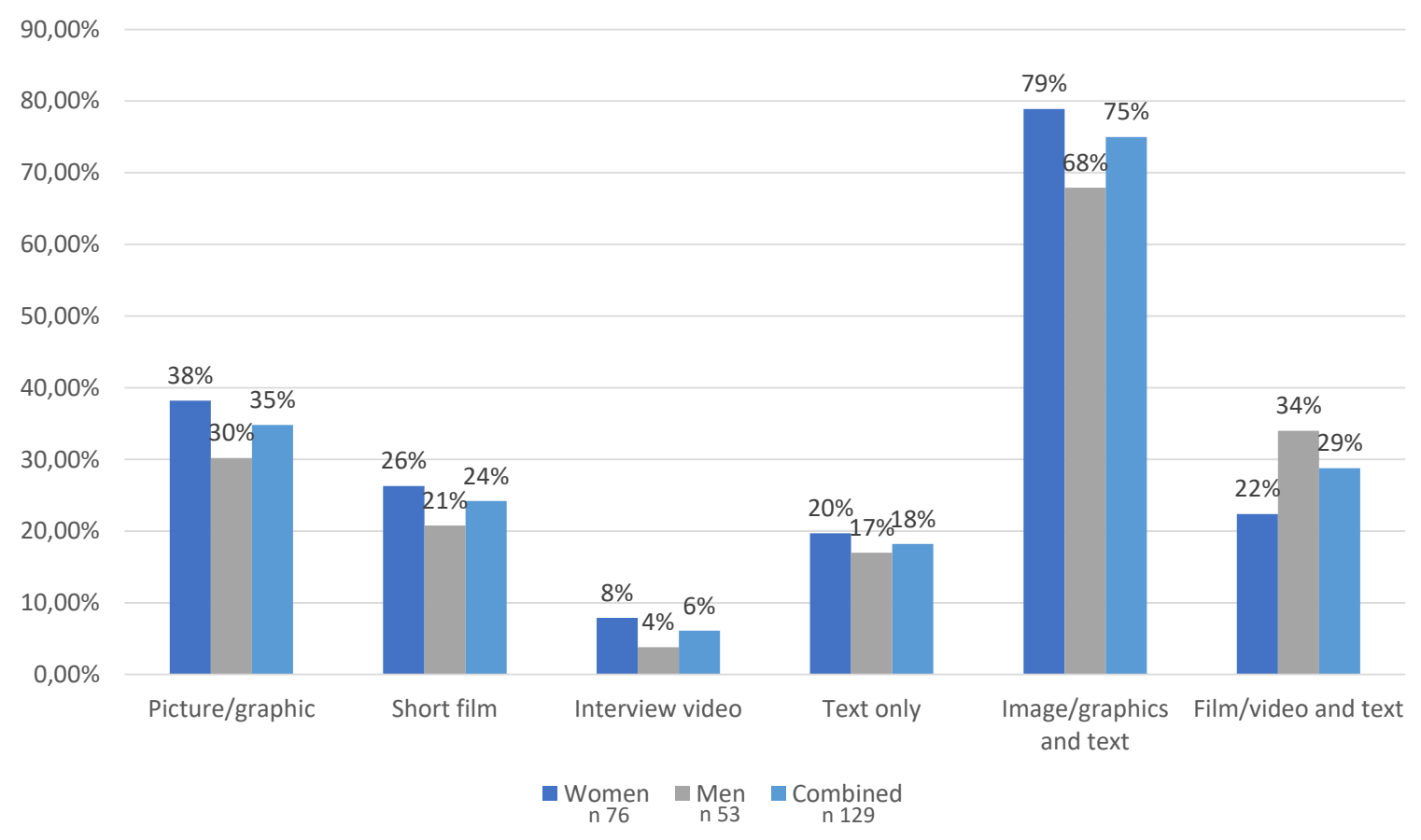

Figure 4: How do you like to be informed by the companies on Social Media?

Source: Own survey

WH8.2 Part of the companies' Social Media strategy concerns the active involvement of customer feedback.

Even if the companies lack a defined Social Media strategy, as can be seen in the previous sections, for all three interviewees, it is important to actively use customer feedback. I3 stated that she does not receive much feedback on Social Media, and she does not ask for feedback on a large scale, such as in the form of an online survey, but instead receives such through direct discussions with customers. This feedback is then also implemented within the framework of possibilities, but the person from whom the criticism originates is not explicitly identified in the improvement.

I 2 also claimed that she receives feedback more through discussions in the shop, but also partly through Social Media appearances. However, she has not yet had to point out changes to the critics, as these customers have actively noticed the improvements themselves.

I1 also answered with approval when the feedback question first came up, but even there, he was more reserved, as he pointed out that not every negative feedback should be taken into account and that he would question everything. When the feedback question was asked, he then stated that he did not actively ask for suggestions for improvement - at least, not in relation to Social Media, but rather to the products. As far as implementation is concerned, I1's attitude was similar in that he did not place a great deal of focus or weight on the criticism he received but he kept it 'in mind'.

WH9 The increased need for information on Corona is also reflected in the structure of companies' Social Media content, with more than half of said content featuring a corona reference.

The Social Media presentations of two of the three SMEs almost exclusively offered information on the Corona topic and the respective company. All three companies also reported in the interview that, at some point, they continued posting, but did not post anything Corona-related (in the first wave). This again revealed a discrepancy between the companies. At Candles, the time for continuing was reached 
relatively quickly - as soon as the 'shock' was processed. In the case of Bakery, according to I1, this point was reached in approximately May after Easter, when private parties were possible again and cake orders resumed. For the last SME, Physiotherapy, the time for resuming other themes was only reached in June/July.

In addition to answering hypotheses 8 and 8.1 , the quantitative survey asked whether the participants believed that their followers' companies had provided sufficient information regarding Corona on the Social Media channels. An estimated $73 \%$ of the women were of the opinion that the companies had provided sufficient information while $64 \%$ of the men shared this belief.

In the following, the questions raised at the beginning of this work are answered and any results not previously discussed are presented. These additional findings are presented here because they were not previously needed to test the working hypotheses, but they do provide a more far reaching view of the theory and state of research presented previously.

\section{How are these reactions to the latest developments communicated?}

According to the Westley \& MacLean communication model, the SMEs surveyed would have to select a theme from a number of different themes $(\mathrm{X} 1-\mathrm{Xn})$ and then adapt this to the channel, where it would in turn be adapted depending on the recipient (Narula, 2006; Perry, 2002; Ries, 2010). The experts interviewed for this study listed different approaches to this task. I3 indicated that possibly counterproductive topics should be selected, such as limiting the number of participants. In addition, they sought to adapt the message to the channel and the corresponding recipients. I1, meanwhile, indicated that counterproductive topics should not be published in Social Media and that a topic will be posted simultaneously and unchanged on all channels he uses. With regard to Corona, I1's themes were chosen in such a way that they are conducive to the company, such as postings regarding the possibility of purchasing yeast and flour from the baking paradise. I2 stated that she would also post negative topics in the future if necessary, such as a product recall, due to her perception that she could not reach her customers otherwise. However, even I 2 does not adapt the news to her two channels. Additionally, I2 has not reacted in any progressive way to the Corona developments, and it was only when the closure was ordered by the state that a reaction was made. It can thus be claimed that the 'reactions' to the latest developments concerning Corona have been communicated differently by each of the interviewed SMEs.

However, what makes the SMEs similar is that, simply because of the information overload and the multitude of possible news items available on a daily basis (especially in the early days of Corona), SMEs in Social Media have to make a choice between content to post, similar to the 'news value theory'. According to this theory, a decision is made for or against reporting on the basis of various dimensions. Depending on whether the event fulfils characteristics in quality, intensity and the combination of these and other characteristics, it is reported or another news item is preferred (Maier, Glogger, Retzbach, \& Stengel, 2018). The subsequent adaptation according to Westley and MacLean, and the use of 'knowledge' resulting from 'intra-transactions' as well as the inclusion of 'para-feedback' according to Früh and Schönbach, is not taking place or is doing so only to a limited extent (Früh, 1991; Klosa, 2016). This could be justified by the characteristics of SMEs. By linking the company's eco-nomic success with the economic existence of entire families, the interviewed experts were initially interested in securing day-to-day business operations and neglected strategic orientation.

\section{How is Social Media used in the communication policy in SMEs?}

Regarding the question of how to use Social Media in SMEs' communication policy, it can now be stated that all three consider the use of Social Media in communication policy as indispensable. At the same time, however, according to the definition of IfM, this use is not particularly strategic regardless of the company's size. None of the interviewed SMEs demonstrated any signs of a planning process of communication policy.

In particular, the component 'Design of the communicative message' (Meffert, Burmann, \& Kirchgeorg, 2013) is not well planned by the companies. Here, I2 and I1 indicated that they do not adapt the message to the respective channel and its target group, but rather feed it in centrally via a tool from 
Facebook Inc. Accordingly, Westley and MacLean's communication model only works to the extent that the choice of channel was made once at the beginning, such as the choice of using Facebook and Instagram in the case of I1. This actively illustrates that he only once included any existing knowledge about the target group in his 'intra-transactions' (according to Früh and Schönbach) leading to the decision (Hoppmann, 2010). If we now examine the last model used in this work by Schulz von Thun, the expert interviews indicated that the SMEs' focus remained on the 'factual level' when designing the message, and the followers, who are mostly also customers of the SMEs, then actively consider the 'appeal level' (Schulz von Thun, 2020). The elaboration of the relationship via Social Media in communication policy, however, is not direct, but rather solely indirect. Additionally, the 'selfrevelation level' is not prominently pursued by the companies. Therefore, at least with regard to the interviewed SMEs and their Social Media appearances, it can be stated that the equivalence of levels intended by Schulz von Thun is not seen or fulfilled by the companies. However, since much of the communication takes place unconsciously and is perceived subjectively by the recipient, the exact understanding of the posts differs from person to person.

Furthermore, in other surveys, the channels selected by the interviewed experts include Facebook and Instagram, the channels most frequently used by Germans (ARD \& ZDF, 2020; EARSandEYES GmbH, 2019; Statista Global Consumer Survey, 2020). Additionally, the alleged obstacle that the interviewed SMEs lack the resources necessary to interact with followers is negligible in light of the survey results, because at least for the questioned participants, it seems to be rather unimportant to interact with the company, and the latest information is decisive for companies to follow Social Media.

\section{Do customers react to this use of Social Media?}

If we now look at the mainly received side of the customers, the quantitative survey first revealed that $63 \%$ of the respondents use Social Media. If we then examine age and gender, we see that especially women between 21 and 30 years of age and women between 51 and 60 years of age use Social Media, but also unsurprisingly, the older the respondents become, the less they use Social Media. However, it is also apparent that companies have chosen the apparently appropriate Social Media channels, because according to this survey, customers predominately use Facebook, Instagram, WhatsApp, and YouTube. All three surveyed companies are present on at least two of the preferred channels. Only WhatsApp is not used by any of the companies for customer communication, possibly due to the terms of use of Instant Messenger or the DSGVO (Elbs, 2019).

The surveyed SMEs utilise Social Media primarily at the 'factual level' and to be present to the customer. The quantitative survey reveals that customers appreciate this focus, as more than $80 \%$ of the participants claimed that the latest information comprises one of the reasons why they follow companies (see Figure 1,2). The percentage was even slightly higher for men (85\%) than women (83\%; see Figure 1). At approximately $60 \%$, the statement 'Interesting content' comes in second. Therefore, the followers' expectations correspond to the use of Social Media by the three interviewed SMEs. Furthermore, the interaction with the company was the least mentioned as a reason for following, and even regarding the importance of the available reasons, only roughly $8 \%$ of the women and $15 \%$ of the men described this as 'very important'. Only the interaction with likeminded people was considered even more irrelevant by $5 \%$ of the women interviewed. The men, meanwhile, rated this as 'very important' with about $21 \%$ (see Figure 2 for what is important). The very idea of Social Media to 'network, communicate and collaborate' does not seem to be considered important by either SMEs or followers of this kind of relationship.

Do SMEs use it actively or, in times of crisis, do they prefer not to use Social Media for communication?

Over the course of this work, it has become clear that Corona has shaped the year 2020 like little else. In almost all areas of life, Corona has changed something, and after the so-called 'first wave' during which this work was largely created, people have adapted and started an almost 'normal' life again in this 'new normal'. As a result, the number of infected people during the 'second wave' significantly increased. In the quantitative survey, $78 \%$ of the interviewees claimed that they were more informed during Corona (see Figure 5). 


\section{Do you have the feeling that you have become more informed during Corona?}

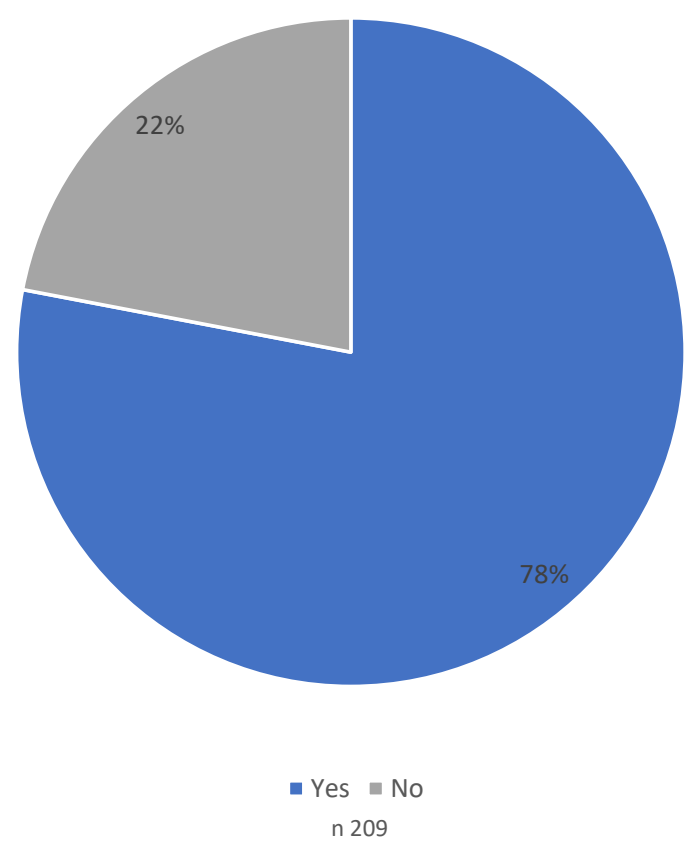

Figure 5: Do you have the feeling that you have become more informed during Corona?

Source: Own survey

However, the behaviour of the interviewed SMEs has, at least in two of the three companies, shifted towards increased and partly different communication with the customers in order to meet the customers' information needs. The quantitative survey has further revealed that the companies have generally succeeded in doing so. Regardless of the use of Social Media, though, the respondents (especially the women) stated that they felt sufficiently informed. If the focus is then placed on Social Media, I3's hope that she has informed her followers sufficiently is confirmed, and therefore, I2's statement is understandable due to the subjectivity that she could have done more in her opinion. Against the background that approximately $74 \%$ of the women and $70 \%$ of the men stated that they felt sufficiently informed by the companies on Social Media platforms, their concerns from the customer/follower perspective are generally unfounded (see Figure 5). However, how their customers specifically felt about Candle \& Co. could not be examined in this survey due to the guaranteed anonymity of the participants. Examining the SME appearances of the surveyed SMEs, the question whether 'communication phases can be identified that are independent of the corporate sector' can be confirmed. The following four phases can thus be identified in the SMEs' Social Media appearances: no postings at all related to Corona, almost exclusive Corona content, a transition phase, and final resumption of normal posting (see Figure 6). 


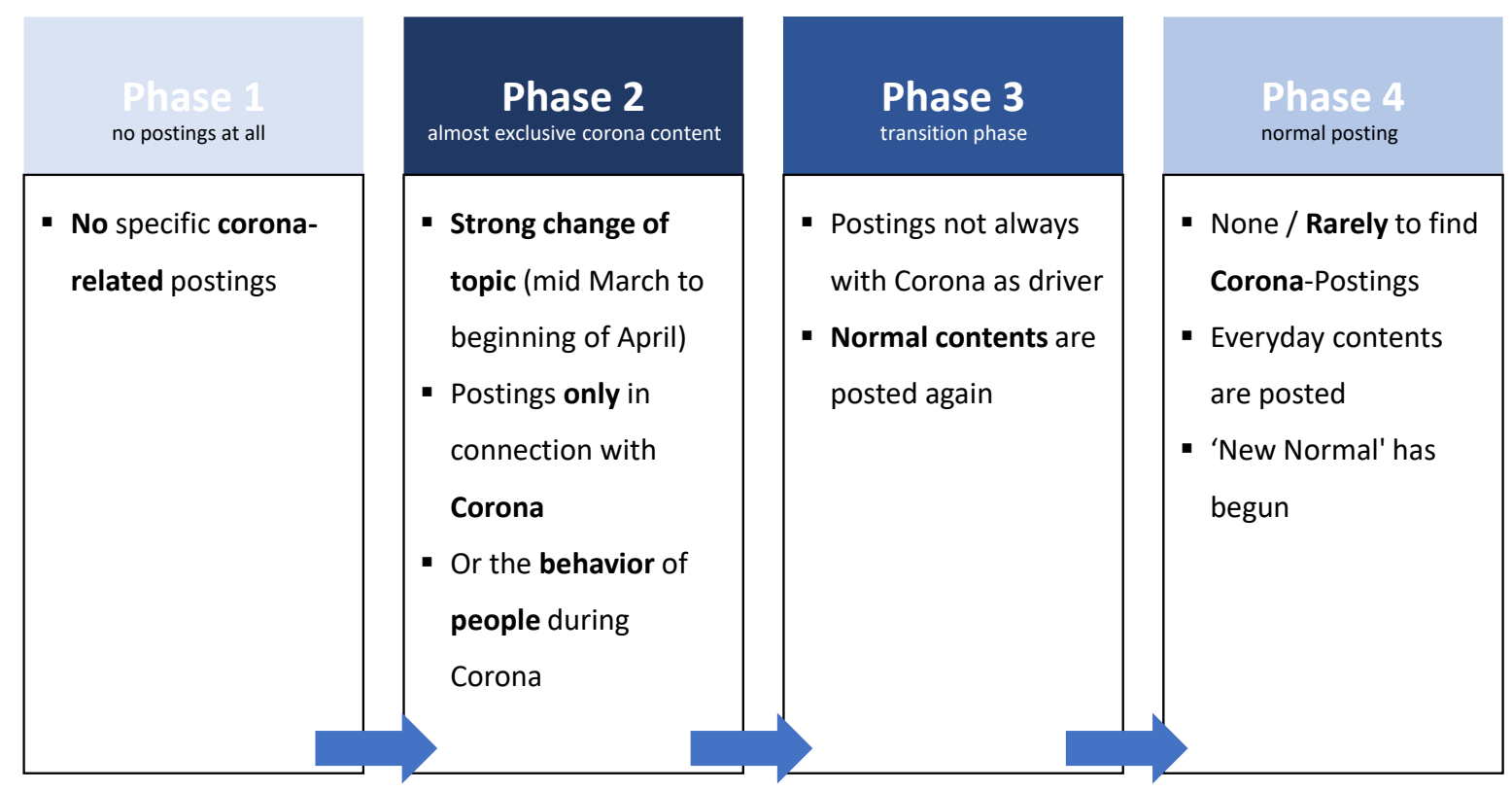

Figure 6: Four phases of Corona information in Social Media

Source: Own presentation

The survey indicates that customers use Social Media for self-information during Corona. However, it was found that little more than half of the interviewees had visited the companies' websites, and men in particular were more likely to drive to the location to check whether the shop was open than to look at Social Media (see Figure 7).

\section{Where did you find out about changes in your preferred companies during Corona?}

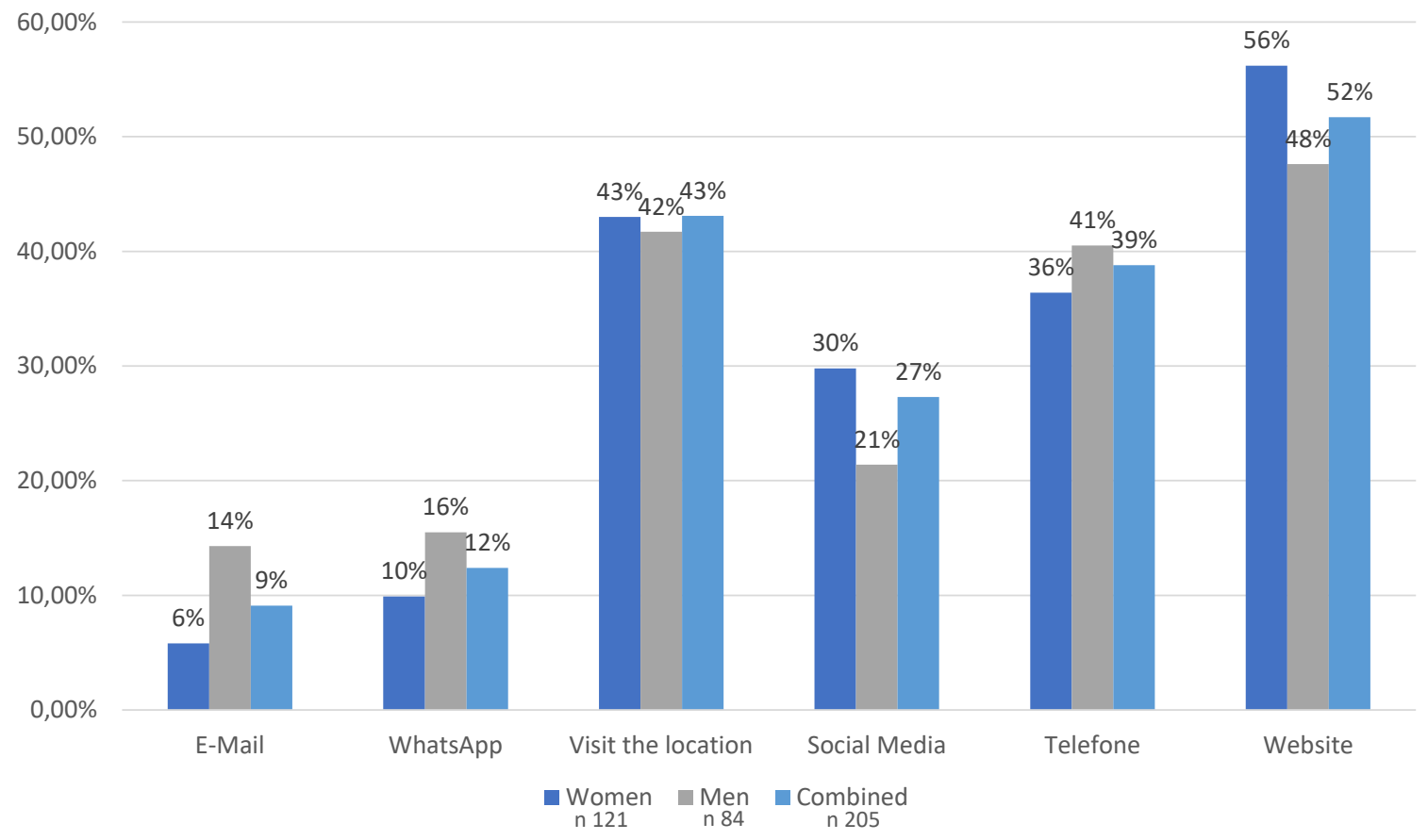

Figure 7: Where did you find out about the changes in your preferred companies during Corona? 


\section{Source: Own survey}

Regardless of whether the respondents use Social Media or not, people up to the age of 70 preferred to inform themselves via the company website or drove to the location; only then does the source of information 'Social Media' follow, with the exception of 21-30-year-old women, who claimed that they were more likely to inform themselves via Social Media than to drive there (see Figure 8). In addition, the text field also indicated that the respondents had obtained information via Google/Internet in general or via radio and TV.

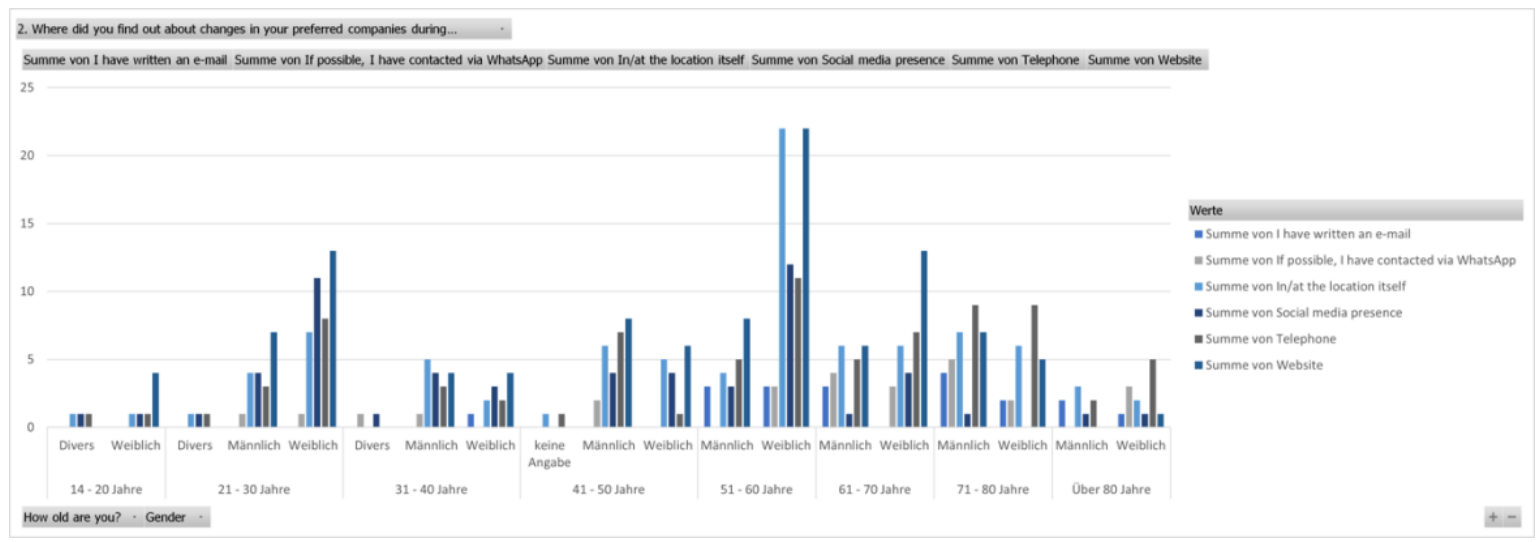

Figure 8: Where did you find out about changes in your preferred companies during Corona answers divided into gender and age.

Source: Own survey

In summary, customers actively use Social Media for information, and obtaining the latest information constitutes the reason for subscribing to a company's Social Media presence. Companies should thus inform during Corona through all available channels, including Social Media with its various forms. In particular, however, the website should be kept up to date, such as in the form of a weblog integrated into the website.

\section{CONCLUSION}

In conclusion, it can be stated that the interviewed companies, likely including numerous entrepreneurs as well as normal consumers, were absolutely taken by surprise by Corona and were or remained exposed to an uncontrollable situation never before seen. During this time, the focus was usually already limited and focussed exclusively on securing the company's own business, the employees involved, and the livelihoods that depend on it, which corresponds to the nature of SMEs. The lack of strategy, combined with limited resources, represented the most challenging obstacles for SMEs' use of Social Media in communication policy even before 'times of crisis'. In previous largescale studies, SMEs have recognised the importance of Social Media in communication with stakeholders, and the SMEs interviewed for this work also consider the use of Social Media to be indispensable. Furthermore, the government has ordered measures to contain the virus, such as by keeping a minimum distance of at least 1.5 metres between persons, as well as other regulations restricting businesses. However, this has still not contributed to a redistribution or a spread of Social Media efforts, such as to intercept physical proximity through digital proximity. Another point that emerged from the interviews concerns the reluctant integration of employees into Social Media activities. In all three SMEs, the bosses were responsible for the Social Media activities, possibly due to limited resources or hierarchical management (which is typical for SMEs), wherein 'the last word is with the boss'. This is disadvantageous in terms of the SMEs' success factors for Social Media and limits the company's 
perspective on Social Media. However, for employee involvement, guidelines would have to be created independently of Corona, for which SMEs lack resources.

Furthermore, it has been found that customers follow companies on Social Media more to obtain the latest information and less to interact with them, though they also become followers to obtain interesting content. One of the success factors here concerns the customers' integration, but according to the experts, this takes place only to the detriment of SMEs and preferably offline, whereby the topic does not or hardly ever relates to Social Media. However, in order to determine what the customers and followers are truly interested in, communication on the topic of Social Media is essential. Especially in Corona times, interaction with customers was neglected in this respect, and even if it was stated in the expert interviews that more enquiries were processed on Social Media, despite the approaches to reviewing the activities, a controlling approach that covers more than, for example, the number of likes under a posting remains lacking.

The aim of this work was to find out more about the use of Social Media in SME communication policies during the Corona crisis. The interviewed experts and the observation of the three SMEs' Social Media appearances revealed that Social Media was employed with the intention of informing the customers during Corona and to stay in their minds, such as by reminding them that the shop is still open (in parts) or that a new service or product is offered. The goal was not to actively cultivate the relationship, maintain closeness between the SME and the customer, or arouse emotions to maintain the relationship, and thus achieve loyalty, which can lead to a repurchase. However, since, according to Schulz von Thun, every message consists of four parts, it can be assumed that the psychographic goals were certainly conveyed in the messages. If, in addition to this, the customers' (offline) reactions are taken into account, as in the case of Candle \& Co., where customers stood at the door with flowers after reopening, it can be assumed that the SMEs have also achieved the relationship management and other non-monetary goals by using Social Media in their communication policy during Corona.

It has further been revealed, that communication with the recipient by means of Social Media begins with selecting the events to be reported. Furthermore, it was found that SMEs use at least some of the knowledge generated in intra-transactions, the message about the selected event is not completely adapted to the respective medium, and the message itself is not or only insufficiently adapted. For at least two of the three SMEs surveyed, this can be explained by their claim that the Social Media channels they use are provided by the same company and that Facebook Inc. offers the 'Facebook Business Manager', which allows a post to be shared in parallel with onetime 'creation' and one-click uploads simultaneously on both connected platforms. Therefore, no adaptation is needed or made.

Additionally, it has been found that communication from the recipient (i.e. the follower) back to the communicator (i.e. the SME) does not take place as continuously as from the communicator to the recipient. Although para-feedback is sent and perceived (e.g. comments or likes under a posting), no inter-transactions take place from which the SMEs actively and progressively gain new knowledge about their followers. This cannot be blamed on the SMEs alone, because the survey conducted for this work indicates that the customers follow companies in order to receive information and interesting content and not to communicate with the company, such as by writing comments or reviews. In this respect, providing a 'thumbs up' takes less time and cognitive capacity.

\section{LIMITATION AND STUDY FORWARD}

This work offers only a limited opportunity to explore the use of Social Media in SMEs' communication policy during Corona. It has not been possible to illustrate exactly what the use of Social Media in communication policy looks like for SMEs that implement or are able to implement all or at least a large part of the success factors presented, because the SME can raise the corresponding resources of all kinds. Furthermore, it could not be revealed how the interviewed experts would have answered the interview questions without the 'Corona' factor. Furthermore, due to only one cooperating company and the omission of traceable links due to anonymity efforts regarding the participants, it could not be investigated how the customers would have answered the respective questions regarding the company at hand. 
During the preparation of this work, however, not only limitations have arisen, but also opportunities for further research efforts. For example, a consideration between SMEs with large companies would offer one way to compare the use of Social Media between large and small companies during Corona. In turn, this would enable taking a closer look at whether access to the necessary resources alone makes the use of Social Media during Corona desirable as well as how customers would perceive and evaluate this likely difference. Furthermore, in light of the second Corona wave, the use of Social Media in SMEs' communication policy could be compared between the first and second or further waves. This could help determine whether the phases identified in the first wave are repeated and, above all, how the followers react to it, such as to be shown only the omnipresent topic 'Corona' again or whether people have already arrived at a 'new normal' in such a way that they only give the latest information as a reason for following Social Media if it is not Corona-related information. In addition to likely numerous other research opportunities, it would also be possible to look back at the interviewed SMEs and determine if anything has changed in their use of Social Media following the interviews. For example, this could include SMEs rethinking the obviously missing Social Media strategy and its subsequent documentation. Alternatively, the interview questions may have resulted in the companies accepting that Social Media is inevitable, as well as prompted them to acquire knowledge about Social Media in order to improve their Social Media presences.

This work represents only a first tentative step in researching the impact of Corona on SMEs. It is intended to provide a first indication of how SMEs have used Social Media during Corona and whether customers appreciate this or whether, in times of global crisis with no end in sight, consumers trust the information provided by traditional media more. This work can thus be classified as a microscopic barometer of a limited, not representative public opinion with the possibility to follow some of the working hypotheses in greater depth.

\section{Acknowledgement}

I would like to thank my supervisors and mentors Prof. Dr. Patrick Siegfried, Prof. Dr. Arne Westermann, Alexander Brewster, Sabine Pillath-Günthner and Elmar Schüller for their consistent support and guidance during the implementation of this project. I would also like to thank the researched companies for their cooperation during the data collection process. I would also like to thank my family and friends for their commitment and all-round support during the study. 


\section{Appendix}

\section{Dear participant}

We all probably imagined the current 20 s to be very different.

Instead, 2020 is marked by the corona crisis, it has influenced our lives and is still omnipresent.

Small and medium-sized enterprises in particular were hard hit by the restrictions, such as the lockdown and the subsequent conditions.

Since during Corona many processes have shifted even more to the digital world and communication via social media has become even more important due to 'social distancing', I made this the topic of my master thesis.

I would like to explore how small and medium-sized companies use or have used social media in their communication with customers during Corona.

It is therefore also important for me to know how you as a customer feel about the use of social media by small and medium-sized companies. For this purpose, I have prepared a short questionnaire which will only take a few minutes of your time.

All the information you provide there is anonymous and will be used exclusively by me to prepare my thesis.

I would like to thank you in advance for your time and honest answer.

Rebecca Spenner

Figure 9: $\quad$ Permission taken for the online survey 


\section{REFERENCES}

A3Marketing (2013, December 12). Studie: Social Media \& KMU. A3 Marketing, pp. 16-17. Retrieved from https://www.wiso-net.de/document/AAA_cf580eb59cad86576a3c3f75ebe8d6b84fe1fe12

AGOF (2020). Corona-Effekte im Netz. Retrieved from https://www.agof.de/agofacts/statistik/coronaeffekte-im-netz/

Ambrosch, T. (2020). Social Media Marketing in KMU - Zahlen und Fakten. Retrieved from https://blog.selectline.de/social-media-marketing-kmu-zahlen-und-

fakten/\#Verbreitung_von_Social_Media_in_Unternehmen_nach_Unternehmensgroesse 7

ARD, \& ZDF (2020). Anteil der Nutzer von Social-Media-Plattformen nach Altersgruppen in Deutschland im Jahr 2020. 2 Retrieved https://de.statista.com/statistik/daten/studie/543605/umfrage/verteilung-der-nutzer-von-social-mediaplattformen-nach-altersgruppen-in-deutschland/

Arns, T. (2012). Social Media in deutschen Unternehmen. Retrieved from https://www.bitkom.org/sites/default/files/file/import/Social-Media-in-deutschen-Unternehmen4.pdf

Bendel, O. (2020). Stichwort: Soziale Medien. Retrieved from https://wirtschaftslexikon.gabler.de/definition/soziale-medien-

52673\#: :text=Soziale\%20Medien\%20(Social\%20Media)\%20dienen,ist\%20wesentlich\%20durch\%2 0sie\%20bestimmt.

Bogner, A., Littig, B., \& Menz, W. (2014). Interviews mit Experten: Eine praxisorientierte Einführung. Lehrbuch. Wiesbaden: Springer VS. https://doi.org/10.1007/978-3-531-19416-5

Braun, V., \& Clarke, V. (2006). Using thematic analysis in psychology. Qualitative Research in Psychology, 3(2), 77-101. https://doi.org/10.1191/1478088706qp063oa

Braun, V., \& Clarke, V. (2013). Successful qualitative research: A practical guide for beginners (First published.). Los Angeles, London, New Delhi: SAGE.

Bruhn, M. (2014). Marketing: Grundlagen für Studium und Praxis. Wiesbaden: Springer Gabler. https://doi.org/10.1007/978-3-658-05112-9

Caprano, C., \& Ergenzinger, R. (2013). Erfolgsfaktoren für das Social Media-Marketing von KMU: Eine qualitativ-explorative Analyse. In J.-A. Meyer (Ed.), Jahrbuch der KMU-Forschung und Praxis ... in der Edition "Kleine und mittlere Untenehmen": Vol. 14.2013. Kommunikation kleiner und mittlerer Unternehmen (Vol. 14, pp. 311-336). Lohmar: Eul.

Cleffmann, L., Feuerabend, A., Kollmann, C., \& Zoebeli, P. (2013). Social Media - Willkommen im Heute: Das ECCO-Handbuch für das Social Web - Ein Leitfaden für Unternehmen und Organisationen. Norderstedt: Books on Demand.

Cook, N. (2008). Enterprise 2.0: How Social Software Will Change the Future of Work. Abingdon, Oxon: Taylor and Francis.

Creditreform (2012, April 5). Social Media: Viele KMU noch überfordert. Creditreform, p. 42. Retrieved from https://www.wisonet.de/document/VCNE_997f554e3eee9f729ee2d6aef0e6f4de7d6b7aeb

Döring, N., \& Bortz, J. (2016). Forschungsmethoden und Evaluation in den Sozial- und Humanwissenschaften (5. vollständig überarbeitete, aktualisierte und erweiterte Auflage). SpringerLehrbuch. Berlin, Heidelberg: Springer. https://doi.org/10.1007/978-3-642-41089-5

EARSandEYES GmbH (2019). Wie regelmäßig nutzen Sie Twitter? Retrieved from https://de.statista.com/statistik/daten/studie/1031294/umfrage/haeufigkeit-der-nutzung-von-twitter-indeutschland/

Elbs, M. (2019). WhatsApp und DSGVO: Das ist aktuell erlaubt. Retrieved from https://www.handwerk-magazin.de/whatsapp-und-dsgvo-was-aktuell-erlaubt-ist/150/519/389729 
European Commission (2003). What is an SME? Retrieved from https://ec.europa.eu/growth/smes/business-friendly-environment/sme-definition_en

Fink, S. [Stefan] (2016a). Ergebnisbericht der Studie Mittelstandskommunikation 2016. Retrieved from https://de.slideshare.net/FFPR/ergebnisbericht-der-studie-mittelstandskommunikation-2016

Fink, S. [Stefan] (2016b). Studie zur Kommunikation im Mittelstan. Retrieved from https://www.ffpr.de/2016/09/20/studie-mittelstandskommunikation-2016-executive-summary/

Fischer, A. (2019). Animation visualisiert Entwicklung populärster sozialer Netzwerke. Retrieved from https://www.turi2.de/aktuell/klick-tipp-animation-visualisiert-aufstieg-und-fall-der-populaerstensozialen-netzwerke/

Fisher, C. M., \& Buglear, J. (2010). Researching and writing a dissertation: An essential guide for business students (3rd ed.). Harlow: Financial Times Prentice Hall.

Fleischer, H. (2018). Handelsgesetzbuch: Mit Einführungsgesetz, Publizitätsgesetz und Handelsregisterverordnung : Textausgabe. dtv Beck-Texte im dtv: Vol. 5002. München: dtv.

Flick, U. (2017). Qualitative Sozialforschung: Eine Einführung (Originalausgabe, 8. Auflage). Rororo Rowohlts Enzyklopädie: Vol. 55694. Reinbek bei Hamburg: rowohlts enzyklopädie im Rowohlt Taschenbuch Verlag.

Früh, W. (1991). Medienwirkungen: Das dynamisch-transaktionale Modell: Theorie und empirische Forschung. Wiesbaden: Verlag für Sozialwissenschaften. https://doi.org/10.1007/978-3-663-10777-4

Hakansson, P.-O., \& Klandt, H. (2000). Das Marketing junger KMUs: Eine Analyse aus Kundenperspektive. In J.-A. Meyer (Ed.), Jahrbuch der KMU-Forschung: Vol. 1.2000. Marketing in kleinen und mittleren Unternehmen (pp. 31-41). München: Vahlen.

Hinterholzer, T., \& Jooss, M. (2013). Social Media Marketing und-Management im Tourismus. Berlin: Springer Gabler. https://doi.org/10.1007/978-3-642-37952-9

Hohmann, K. (2020). Social Media: Verschlafen KMU ihre Chance? Retrieved from https://schluetersche.de/2020/06/23/social-media-verschlafen-kmu-ihre-chance/

Hoppmann, T. K. (2010). Citizen perceptions of the European Union: The impact of the EU web site. Zugl.: Hamburg, Univ., Hans-Bredow-Institut für Medienforschung, Diss., 2009 u.D.T.: Hoppmann, Talke Klara: Images enacted via the EU website. Amherst, NY: Cambria Press.

IfM Bonn (2019). IfM Flyer. Retrieved from https://www.ifmbonn.org/fileadmin/data/redaktion/ueber_uns/ifm-flyer/IfM-Flyer-2019.pdf

IfM Bonn (2020a). Die 10 häufigsten Fragen rund um den Mittelstand in Deutschland. Retrieved from https://www.ifm-bonn.org/definitionen/faq-fragen-zum-mittelstand/

IfM Bonn (2020b). KMU-Definition des IfM Bonn. Retrieved from https://www.ifmbonn.org/definitionen/kmu-definition-des-ifm-bonn/

Immerschitt, W., \& Stumpf, M. (2019). Employer Branding für KMU: Der Mittelstand als attraktiver Arbeitgeber. Wiesbaden: Springer Fachmedien. https://doi.org/10.1007/978-3-658-23133-0

Industrieanzeiger. Social Media ist kein Erfolgsfaktor für KMU. Industrieanzeiger, p. 7. Retrieved from https://www.wiso-net.de/document/IA_3da6399d005c814ad78d4f00a8cb1330f10f6ecf

It\&t (2014, February 14). Social Media kein Erfolgsfaktor für KMU. It\&T, p. 45. Retrieved from https://www.wiso-net.de/document/ITT__a4890b9ae68e12081e9d65a24e7360420d587295

Klosa, O. (2016). Online-Sehen: Qualität und Akzeptanz von Web-TV. Schriften zur Medienproduktion. Wiesbaden: Springer Vieweg. https://doi.org/10.1007/978-3-658-15182-9

Knickmeier, A., Esslinger, J., \& Schwering, M. G. (2013). Twittern, bloggen, innovieren? Explorative Befunde zu edn Potenzialen und Anwendungen von Social Media in Innovationsprozessen kleiner und mittlerer Unternehmen. In J.-A. Meyer (Ed.), Jahrbuch der KMU-Forschung und-Praxis ... in der 
Edition "Kleine und mittlere Untenehmen": Vol. 14.2013. Kommunikation kleiner und mittlerer Unternehmen (pp. 357-377). Lohmar: Eul.

Krämer, J. (2014). Mittelstand 2.0: Typabhängige Nutzungspotenziale von Social Media in mittelständischen Unternehmen. Zugl.: Bamberg, Otto-Friedr.-Univ., Diss., 2014. Unternehmensführung \& Controlling. Wiesbaden: Springer Gabler. https://doi.org/10.1007/978-3-65805600-1

Kreutzer, R. T. (2018). Social-Media-Marketing kompakt: Ausgestalten, Plattformen finden, messen, organisatorisch verankern. Wiesbaden: Springer Gabler. https://doi.org/10.1007/978-3-658-21147-9

Kurz, A., Stockhammer, C., Fuchs, S., \& Meinhard, D. (2009). Das problemzentrierte Interview. In R. Buber \& H. H. Holzmüller (Eds.), Gabler-Lehrbuch. Qualitative Marktforschung: Konzepte - Methoden - Analysen (2nd ed., pp. 463-475). Wiesbaden: Gabler. https://doi.org/10.1007/978-3-8349-9441-7_29

Maier, M., Glogger, I., Retzbach, J., \& Stengel, K. (2018). Nachrichtenwerttheorie (2. Auflage). Baden-Baden: Nomos Verlagsgesellschaft mbH \& Co. KG. https://doi.org/10.5771/9783845284934

MAXQDA (2021). Thematische Analyse. Retrieved from https://www.maxqda.com/wp/wpcontent/uploads/sites/2/MQIC-2019_Spotlight_Handout_DE_thematische-Analyse.pdf

Meffert, H., Burmann, C., \& Kirchgeorg, M. (2013). Marketing Arbeitsbuch: Aufgaben - Fallstudien Lösungen. Meffert-Marketing-Edition. Wiesbaden: Gabler.

Meyer, J.-A. (Ed.) (2000). Jahrbuch der KMU-Forschung: Vol. 1.2000. Marketing in kleinen und mittleren Unternehmen. München: Vahlen.

Meyer, J.-A. (Ed.) (2013). Jahrbuch der KMU-Forschung und -Praxis ... in der Edition "Kleine und mittlere Untenehmen": Vol. 14.2013. Kommunikation kleiner und mittlerer Unternehmen. Lohmar: Eul.

Munz, M. (2018). Soziale Medien: Kleine und mittelständische Unternehmen schöpfen ihr Potenzial nicht aus. Retrieved from https://www.hs-rm.de/de/hochschule/aktuelles/details/artikel/sozialemedien-kleine-und-mittelstaendische-unternehmen-schoepfen-ihr-potenzial-nicht-aus

Narula, U. (2006). Communication models: Communication models. New Delhi, India: Atlantic Publishers \& Dist.; Atlantic.

Paulsen, N., Nietan, M. A., \& Klöß, S. (2020). Social-Media-Nutzung steigt durch Corona stark an. Retrieved from https://www.bitkom.org/Presse/Presseinformation/Social-Media-Nutzung-steigtdurch-Corona-stark-an\#item-6461

Perry, D. K. (2002). Theory and research in mass communication: Contexts and consequences. LEA's communication series. New York: Routledge.

Raab-Steiner, E., \& Benesch, M. (2012). Der Fragebogen: Von der Forschungsidee zur SPSSAuswertung (3., aktualisierte und überarb. Aufl.). UTB Schlüsselkompetenzen: Vol. 8406. Wien: Facultas-Verl.

Reinemann, H. (2011). Mittelstandsmanagement: Einführung in Theorie und Praxis. Wiesbaden: Springer Gabler. Retrieved from https://bilder.buecher.de/zusatz/32/32653/32653484_lese_1.pdf

Ries, C. (2010). Public Relations und Mitarbeiterkommunikation von Wachstumsunternehmen: Untersuchung der Kommunikationskonzepte stark wachsender Unternehmen im deutschsprachigen Raum. Hamburg: Verlag für Sozialwissenschaften ist Teil der Fachverlagsgruppe.

Saunders, M. N., Lewis, P., \& Thornhill, A. (2015). Research Methods for Business Students (7th ed.). Harlow, United Kingdom: Pearson Education Limited. Retrieved from https://ebookcentral.proquest.com/lib/swb/detail.action?docID=5175059

Schmidt, A., \& Hoyer, J. (2012, February 1). Social CRM: Wie sich kleine und mittlere Unternehmen im sozialen Netzwerken Ihrer Kunden platzieren. ERP Managemt, pp. 32-35. Retrieved from https://www.wiso-net.de/document/ERP_e15a99ab607b8b3836da1a9f4d051b2679c61d5f 
Schmidt, J. (2006). Social Software: Onlinegestütztes Informations-, Identitäts- und Beziehungsmanagement. Forschungsjournal Neue Soziale Bewegungen, 19(2), 37-47. Retrieved from forschungsjournal.de/sites/default/files/archiv/FJNSB_2006_2.pdf

Schulz, A., \& Leder, S. (2013). Kommunikation von kleineren und mittleren Unternehmen. In J.-A. Meyer (Ed.), Jahrbuch der KMU-Forschung und -Praxis ... in der Edition "Kleine und mittlere Untenehmen": Vol. 14.2013. Kommunikation kleiner und mittlerer Unternehmen (Vol. 14, pp. 381390). Lohmar: Eul.

Schulz von Thun (2020). Das Kommunikationsquadrat. Retrieved from https://www.schulz-vonthun.de/die-modelle/das-kommunikationsquadrat

Schwartz, M., \& Gerstenberger, J. (2020). Corona-Krise im Mittelstand: Rückkehr zu voller Wirtschaftsaktivität in weiter Ferne, aber Lockerungen entspannen Liquidität. Retrieved from https://www.kfw.de/PDF/Download-Center/Konzernthemen/Research/PDF-Dokumente-FokusVolkswirtschaft/Fokus-2020/Fokus-Nr.-294-Juni-2020-Corona-Mittelstand-2.pdf

Stainton Rogers, W. (2011). Social psychology (2nd ed.). Maidenhead, Berkshire, England: McGraw Hill Open University Press. Retrieved http://search.ebscohost.com/login.aspx $?$ direct=true $\&$ scope $=$ site $\& d b=n l e b k \& d b=n l a b k \& A N=375111$

Statista Global Consumer Survey (2020). Welche Arten von Social Media nutzen Sie regelmäßig? Retrieved from https://de.statista.com/prognosen/999854/umfrage-in-deutschland-zu-beliebten-artenvon-social-media

Tagesschau (2020). Der Ausbruch einer Pandemie. Retrieved from https://www.tagesschau.de/faktenfinder/hintergrund/corona-chronik-pandemie-101.html

Ulrich, P. (2011). Corporate Governance in mittelständischen Familienunternehmen: Theorien, Feldstudien, Umsetzung. Zugl.:Bamberg, Univ., Diss., 2010. Unternehmensführung und Controlling. Wiesbaden: Gabler / Springer Fachmedien. https://doi.org/10.1007/978-3-8349-6183-9

Weis, F., Hofer-Fischer, S., \& Kremmel, D. (2013). Erfolgsfaktoren integrierter Social--MediaKommunikation. Retrieved from https://www.kmu-magazin.ch/marketing-vertrieb/erfolgsfaktorenintegrierter-social-media-kommunikation

Winkler, L. (2020). Organisationskommunikation im Mittelstand: Genese und Spezifik der Kommunikation mittelständischer Industrieunternehmen. Organisationskommunikation, Studien zu

Public Relations/Öffentlichkeitsarbeit und Kommunikationsmanagement: Verlag für Sozialwissenschaften. https://doi.org/10.1007/978-3-658-29283-6

Wintermann, O., Baethge, C. B., \& Boberach, M. (2018). Zukunft der Arbeit in deutschen KMU. Gütersloh. Retrieved from https://www.bertelsmannstiftung.de/fileadmin/files/BSt/Publikationen/GrauePublikationen/Zukunft_der_Arbeit_in_deutschen_ KMU_Werkstattbericht.pdf

Zerfaß, A., $\quad$ Fink, S. [Stephan], \& Winkler, L. (2016, September 20). Studie Mittelstandskommunikation 2016- Presseinformation. Retrieved from https://www.ffpr.de/2016/09/20/studie-mittelstandskommunikation-2016/

Atıf İçin: Spenner, R. ve Siegfried, P. (2021). The Use of Social Media in the Communication Policy of SME's in the Covid-19 Crisis, Yeni Medya Elektronik Dergisi, 5 (3), 286-313 